حسني أنعام سالم تغريد رضوان المومني

المجلد الثاني عشر العدد (22) 2021م ألمريد رضوان المومي

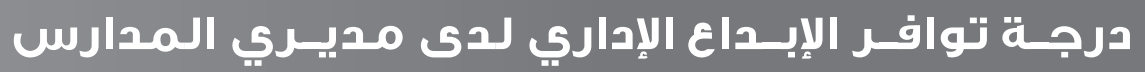

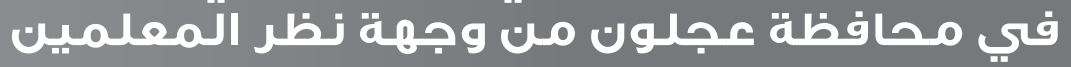

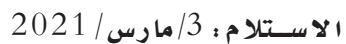

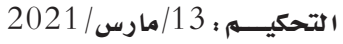

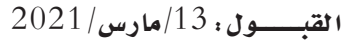

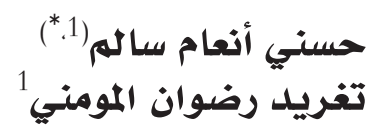

(c) 2021 University of Science and Technology, Yemen. This article can be distributed under the terms of the Creative Commons Attribution License, which permits unrestricted use, distribution, and reproduction in any medium, provided the original author and source are credited.

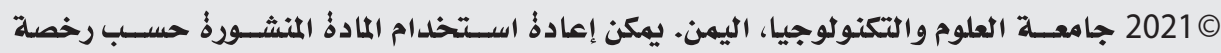
مؤسسة المشاع الإبداعي شريطة الاستشهاد بالمؤلف والمجلة. 
درجة توافر الإبداع الإداري لدى مديري المدارس في محافظة عجلون من وجهة نظر المعلمين المدارسين

الملخص:

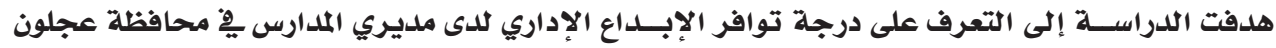

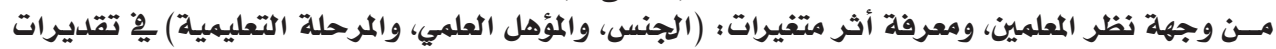

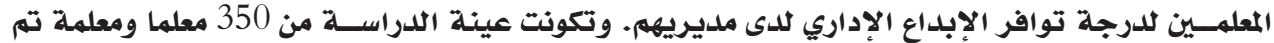

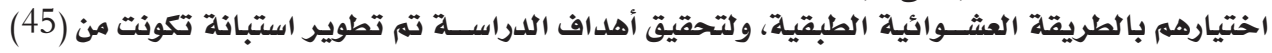

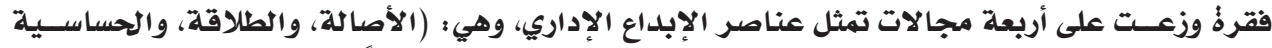

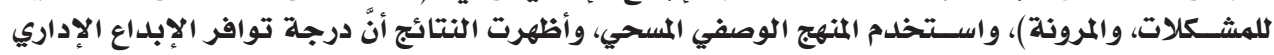

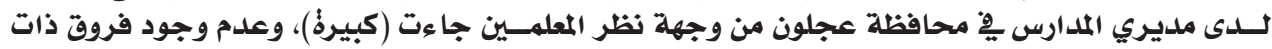

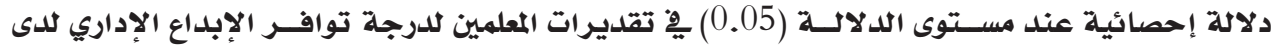

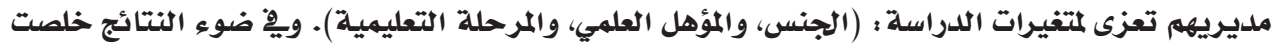

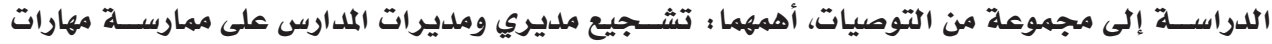

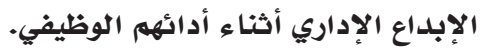
الكلمات المفتاحية : الإبلاع الإداري، مديري المدارس، المعلمين، محافظة عجلون. 
حسني أنعام سالم تغريل رضوان المومني

المجلد الثاني عشر العدد (22) 2021م ألمان رومئ

\title{
Availability Degree of Administrative Creativity among School Principals in Ajloun Governorate from the Perspective of Teachers
}

\begin{abstract}
:
The purpose of this study was to investigate the availability degree of administrative creativity among school principals in Ajloun governorate from the perspective of teachers, and to identify the impact of the variables (gender, academic qualification and educational stage) on teachers' assessment. The sample of the study consisted of (350) teachers selected by the stratified random method. To achieve this, the descriptive survey method was used and a questionnaire consisted of (45) items was developed, covering four dimensions: (originality, fluency, sensitivity to problems and flexibility). The results showed that the availability degree of administrative creativity among school principals in Ajloun governorate from the perspectives of teachers was (high). There were also no significant statistical differences at $(\boldsymbol{\alpha}=0.05)$ in teachers' assessment due to the variables (gender, academic qualification and educational stage). In light of the results, a set of recommendations were proposed.
\end{abstract}

Keywords: administrative creativity, principals, teachers, Ajloun Governorate. 


\section{المقدمة:}

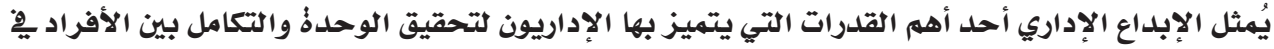

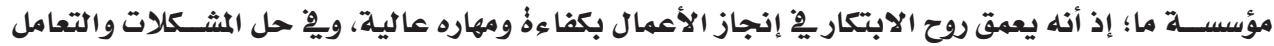

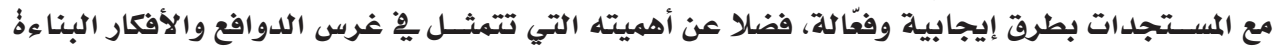

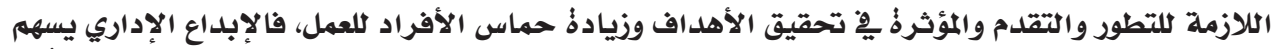

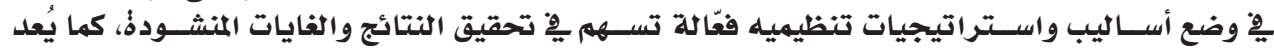

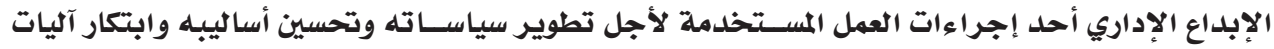

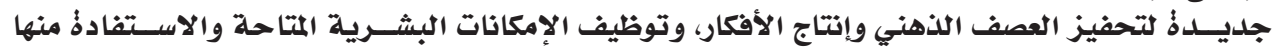

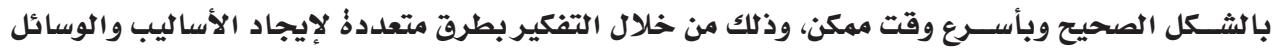

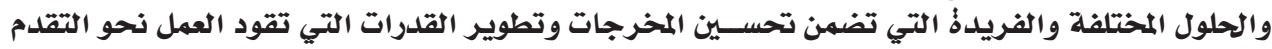
وتحقيق النجاح (Kodama, 2017).

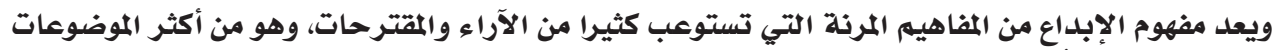

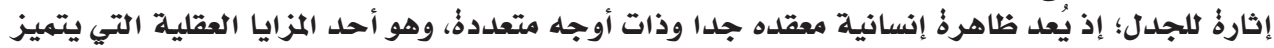

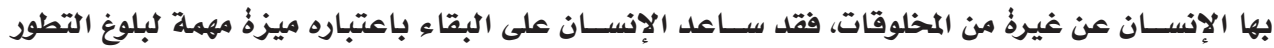

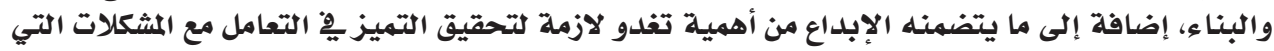

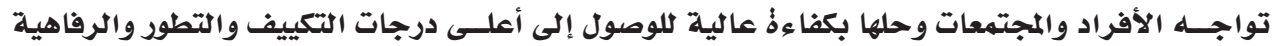
(Shaheen, 2018)

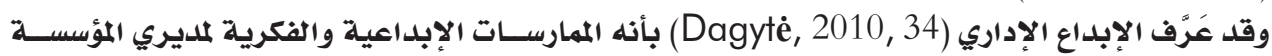

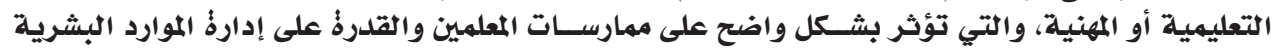

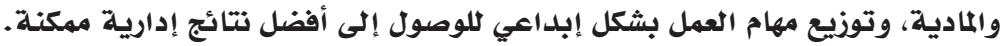

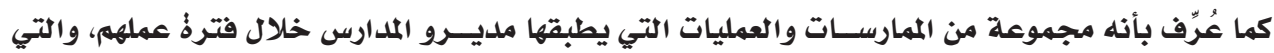

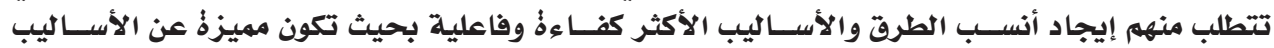

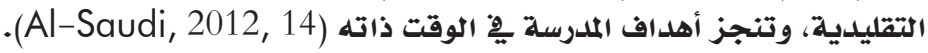

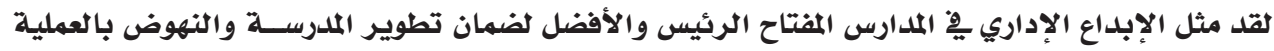

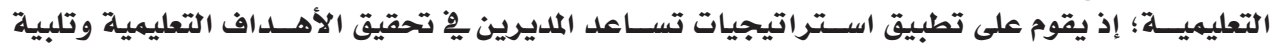

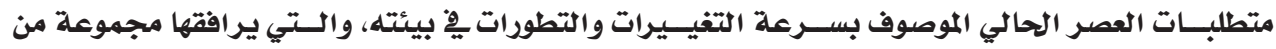

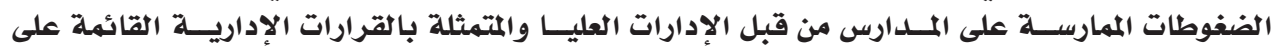

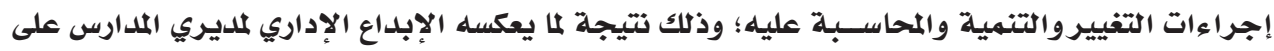

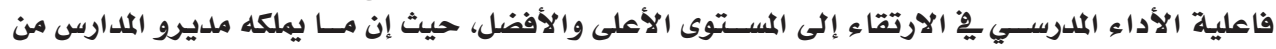

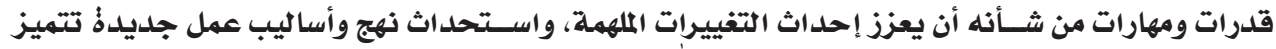

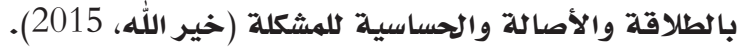

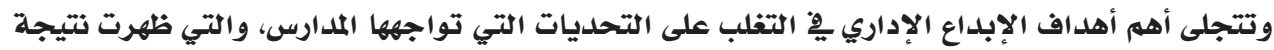

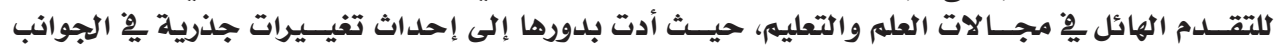

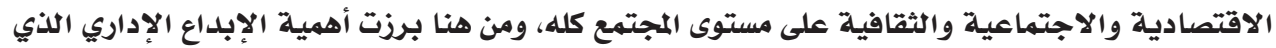

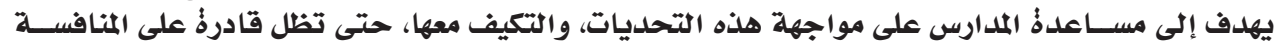

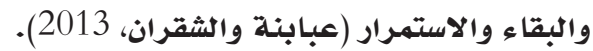

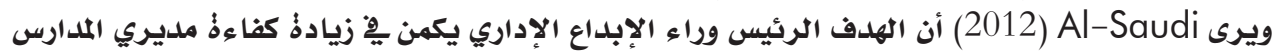

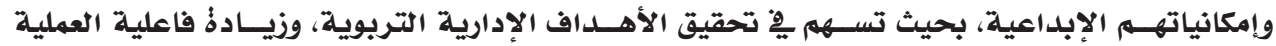

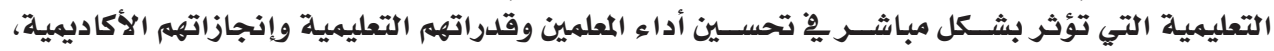

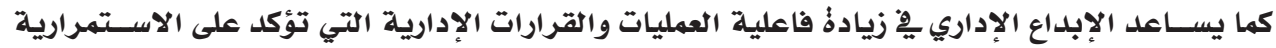
وتحقيق النجاح والتميز. 


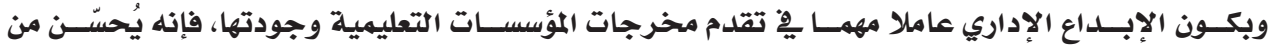

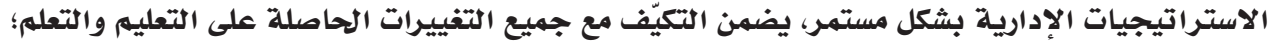

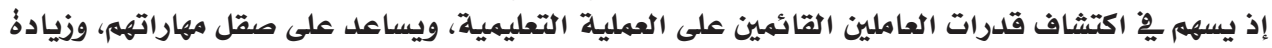

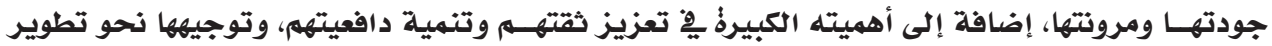
أساليب تدريسية جديدةٌ تخدم العملية التعليمية وترفع من كفاءتها (Hewison \& Holden, 2016).

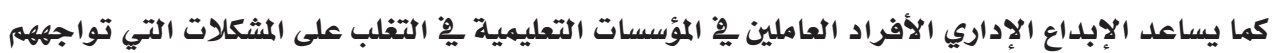

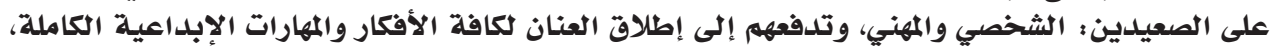

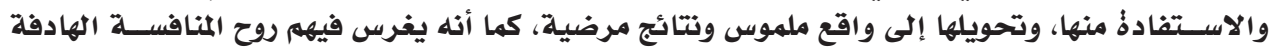

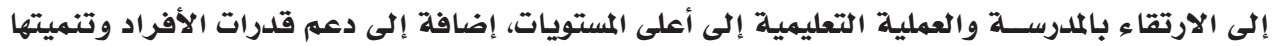

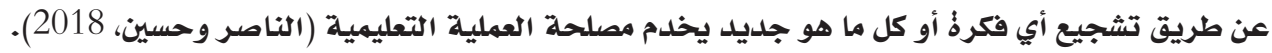

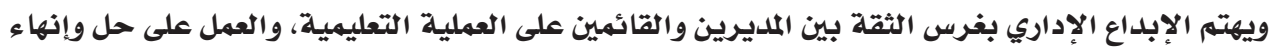

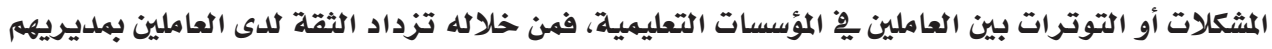

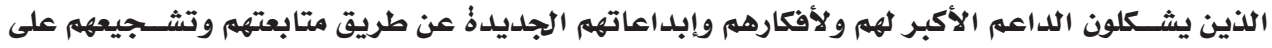

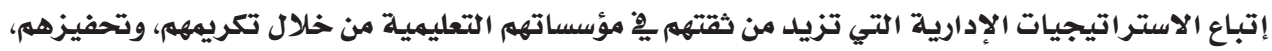

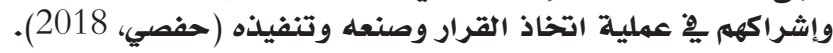

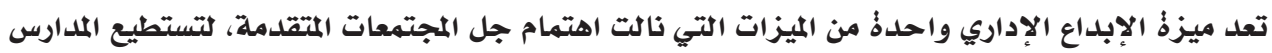

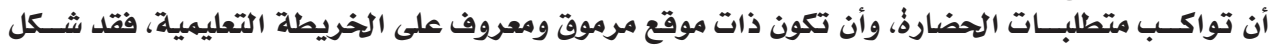

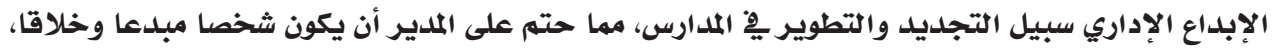

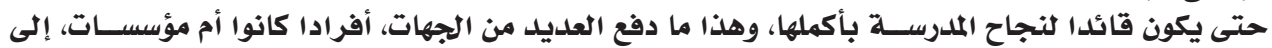
السعي لتوظيف الإبلاع الإداري كجزء لاع يتجزأ من منهجهم (مرعي، 2014).

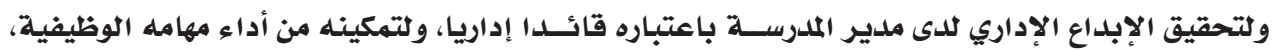

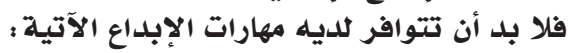

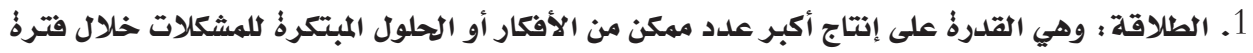

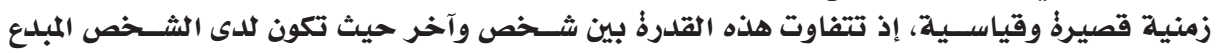

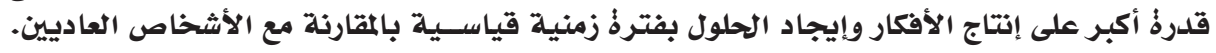

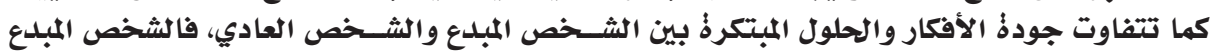

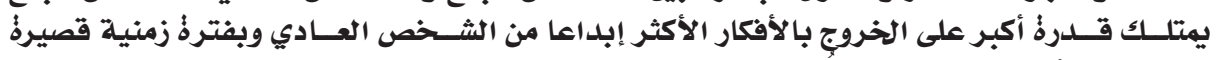

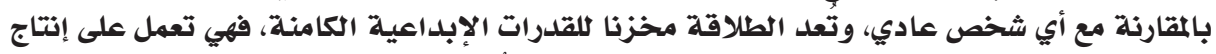

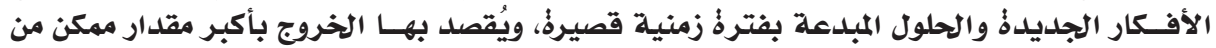

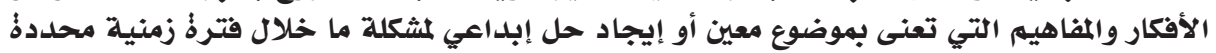
(أهل، 2009).

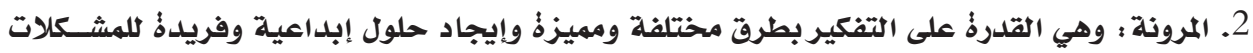

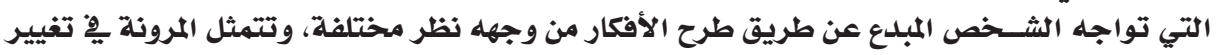

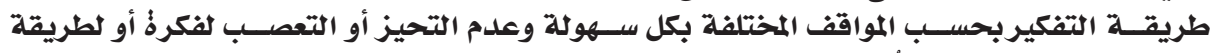

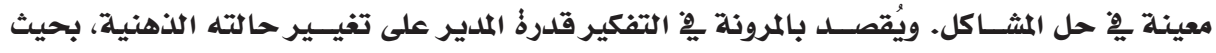

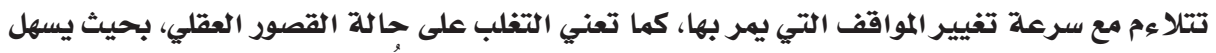

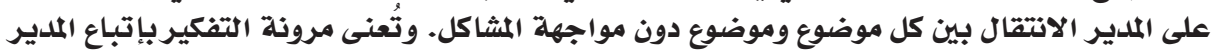

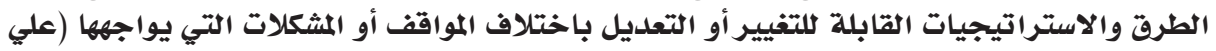




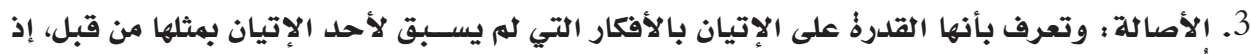

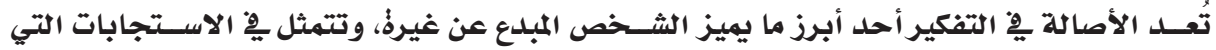

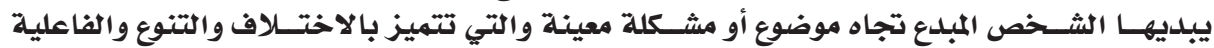

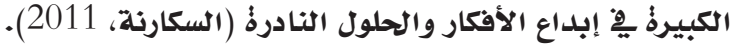

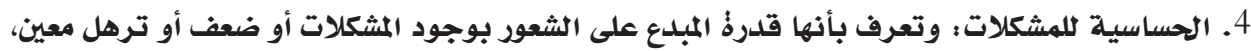

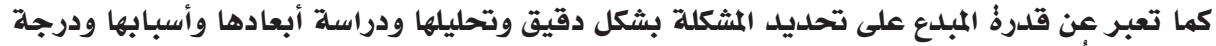

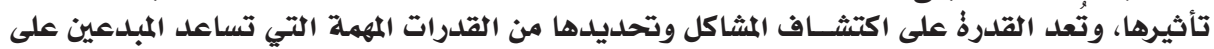

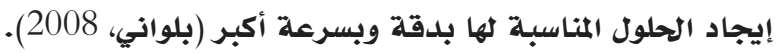

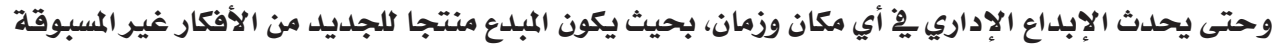

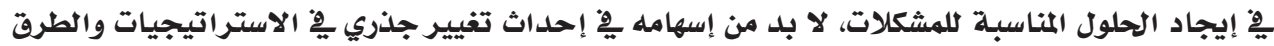

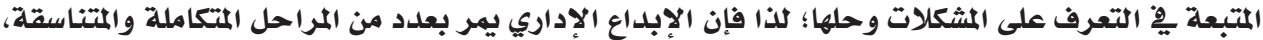

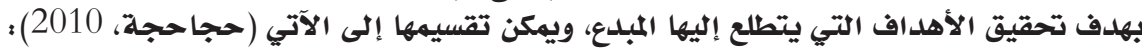

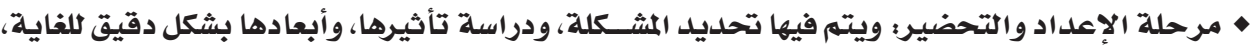

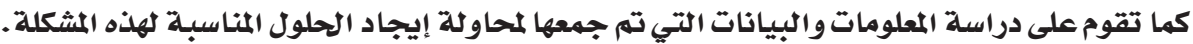

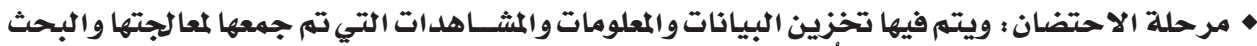

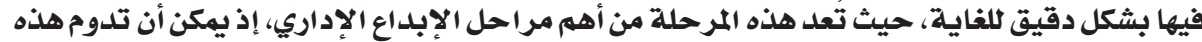

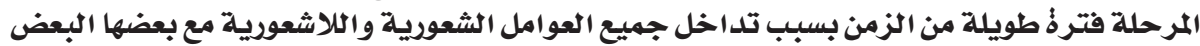

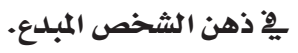

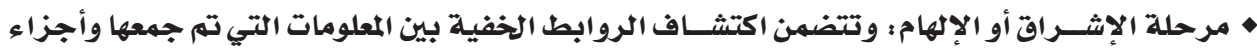

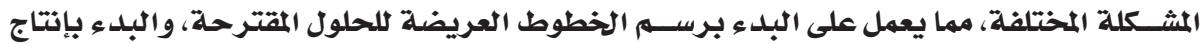

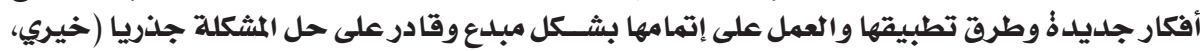
(2012

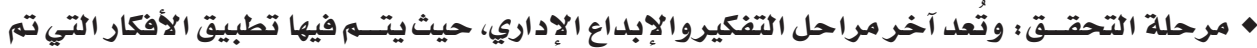

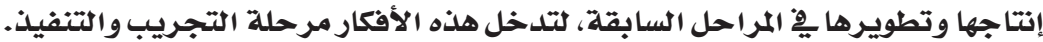

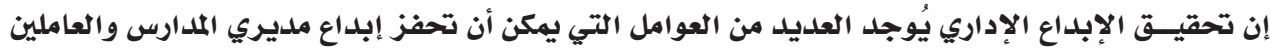

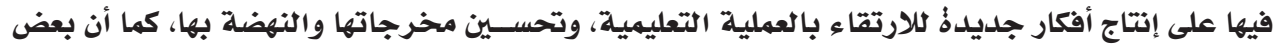

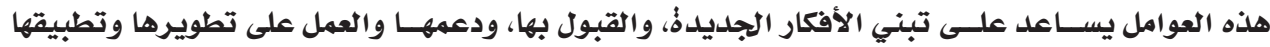

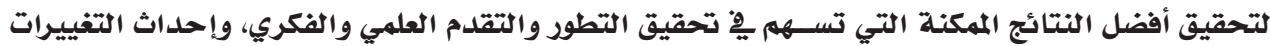

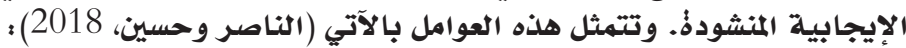

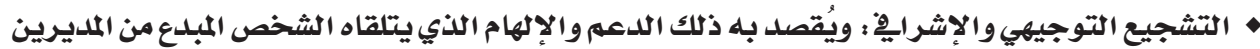

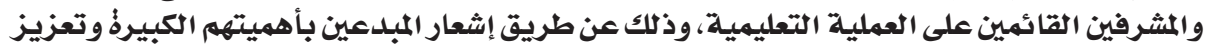
ثقتهم بأنفسهر.

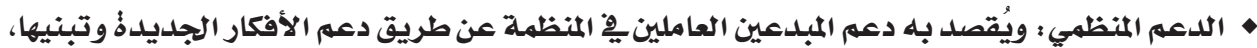

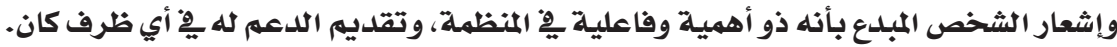

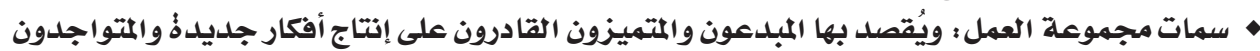

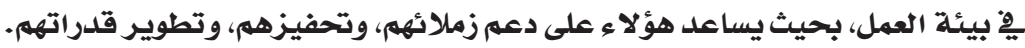

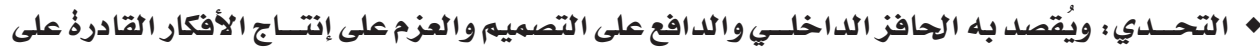

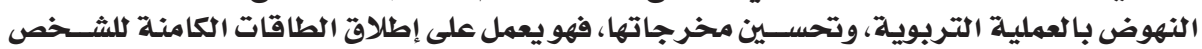

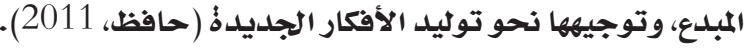


حسني أنعام سالم تغريد رضوان المومني

المجلد الثاني عشر العدد (22) 2021م ألمريد رضوان المومي

$\dot{0}$

وانطلاقا من أهمية الإبداع الإداري، فقد أجريت بعض الدراسات التي سعت إلى الكشف عن أهمية توافر الإبلداع للدى ملديري المدارس، ومنها الإعال

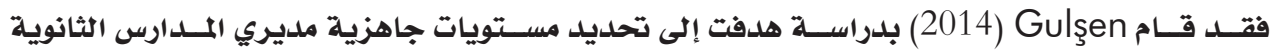

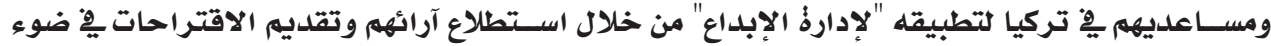

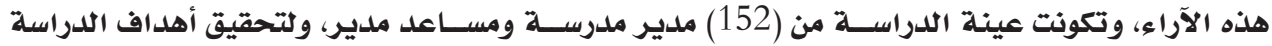

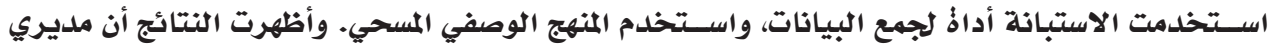

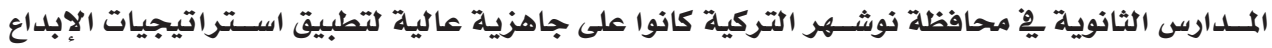

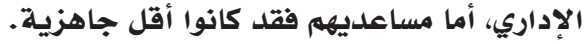

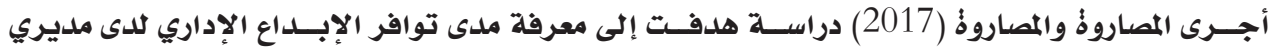

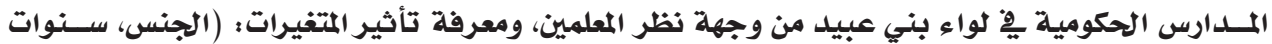

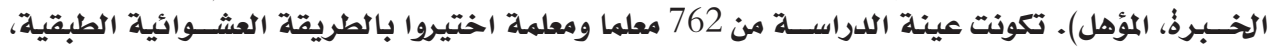

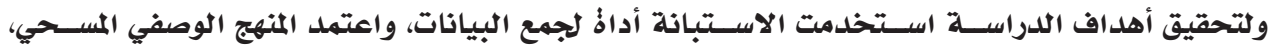

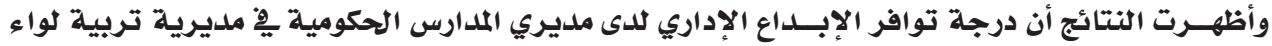

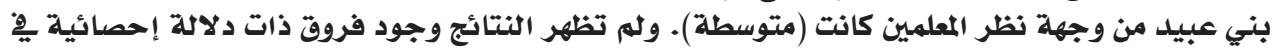
تقديرات المعلمين تعزى لمتغيرات الدراسة : (الجنس، وسنوات المعات الخبرةُ، والمؤهل).

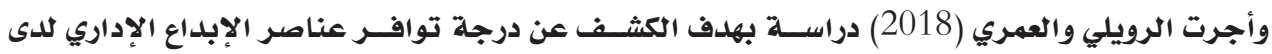

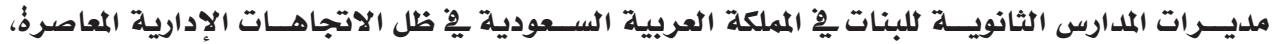

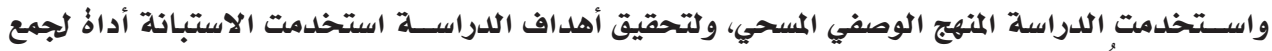

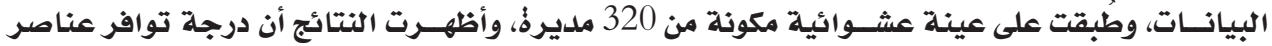

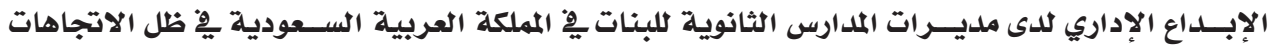

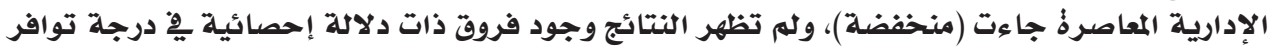

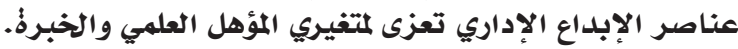
كما أجرى الحشـحوث (2018) دراسة هدفت إلى التعرف على واقع الإبداع الإداري للدى ملديري المدارس إنس

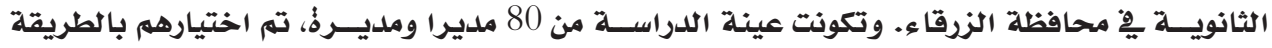

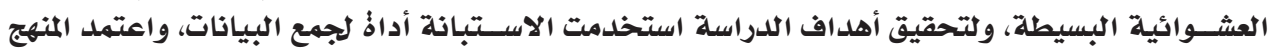

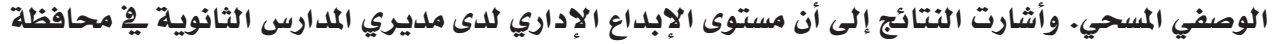

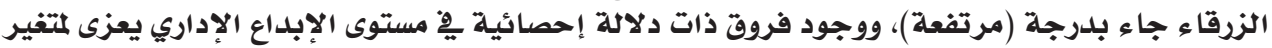

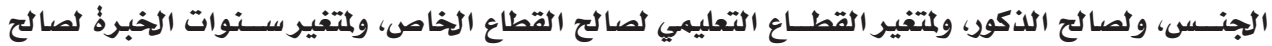

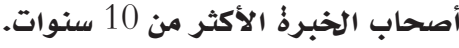

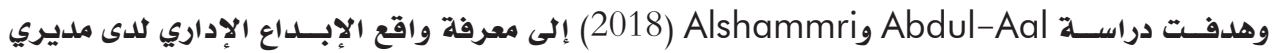

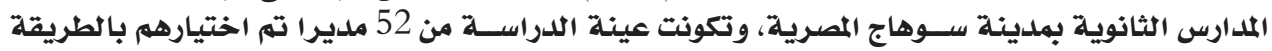

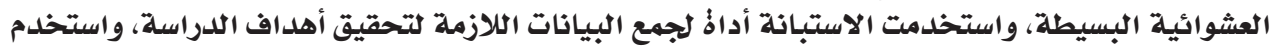

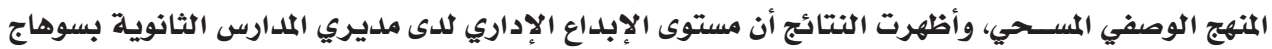

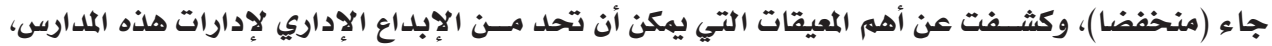

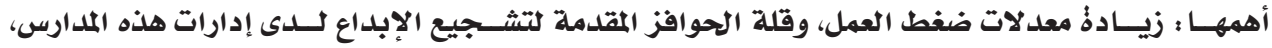

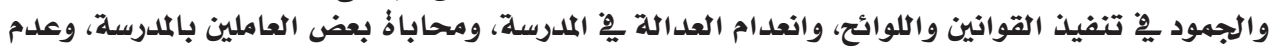

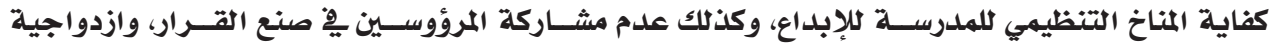

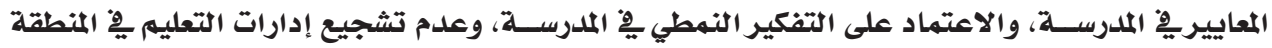

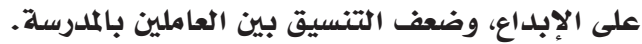


وهدفت دراســة غالطي (2020) إلى معرفة مســتوى توافر عناصر الإبلداع للدى الملديرين بمحافظة صبئيا،

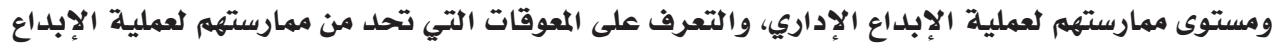

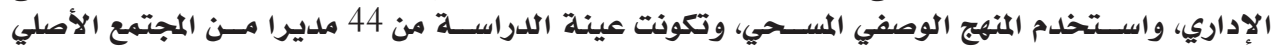

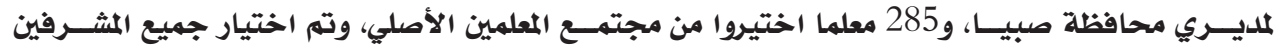

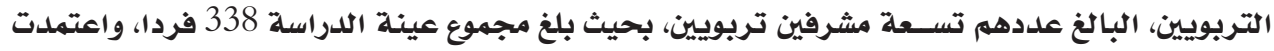

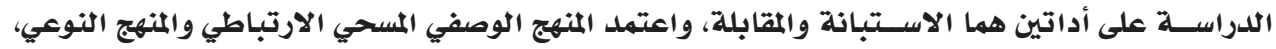

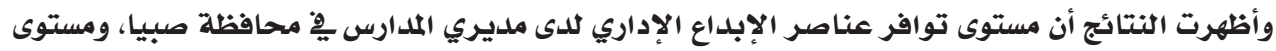

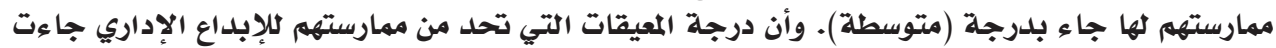

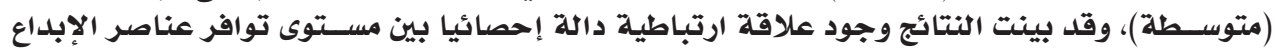

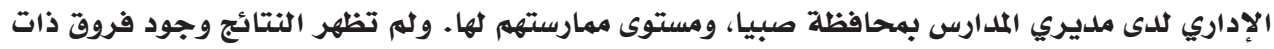

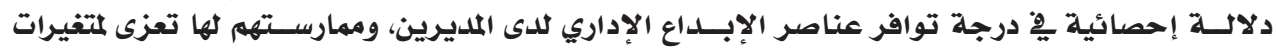

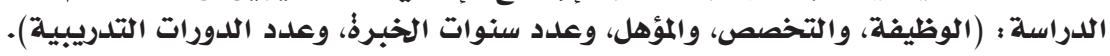

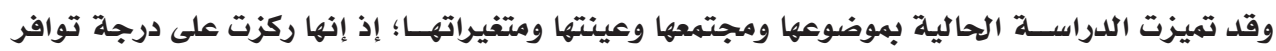

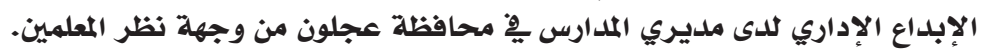

\section{مشكلة الدراسة وأسئلتها:}

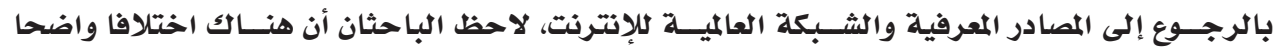

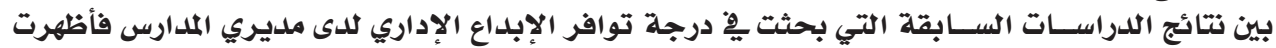

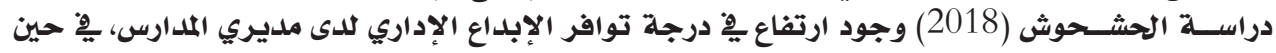

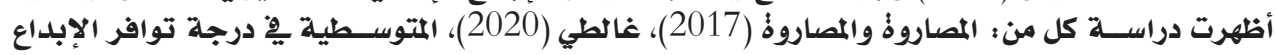

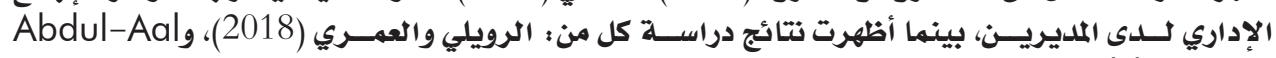

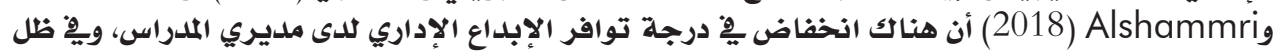

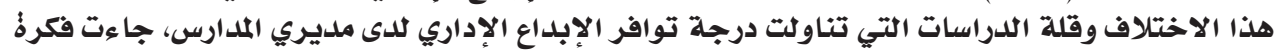

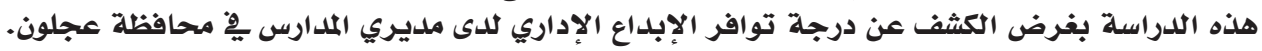

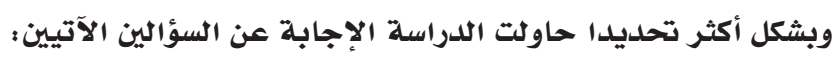

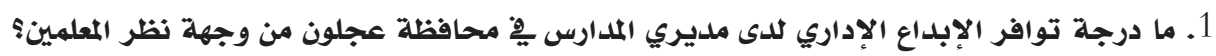

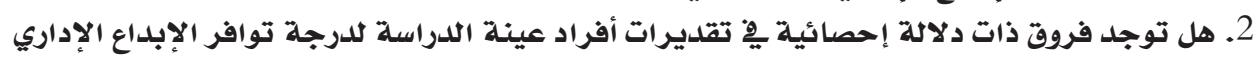

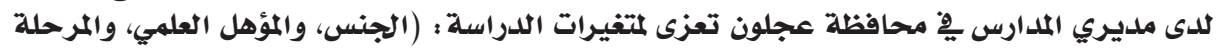
التعليمية)؟ ملايري

$$
\text { أهـداف الدراسة: }
$$

سعت الدراسة الحالية إلى تحقيق الأهداف الآتية :

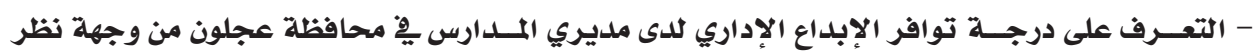

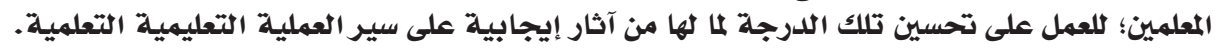

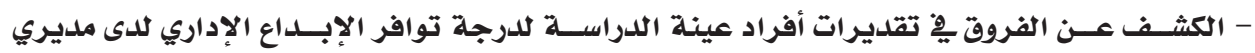

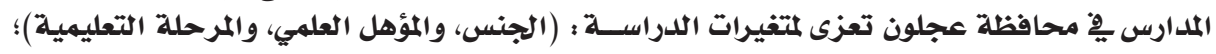

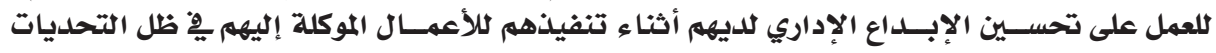
المعاصرةٌ التي تواجه عملية الإبـ التعلم والتعليه. 
حسني أنعام سالم تغريد رضوان المومني

المجلد الثاني عشر العدد (22) 2021م ألمريد رضوان المومي

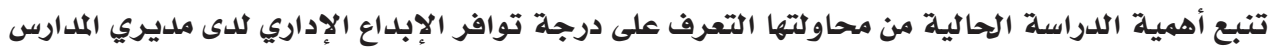

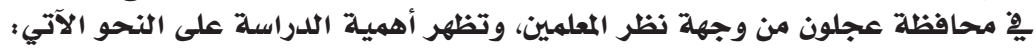

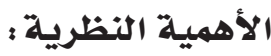

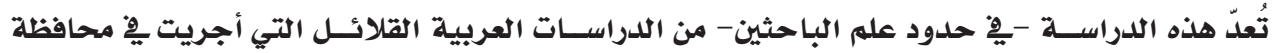

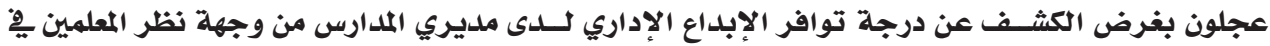

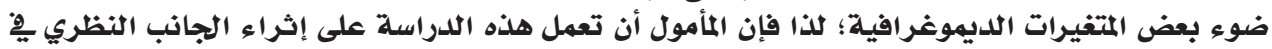

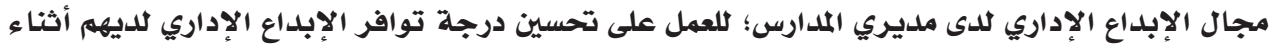

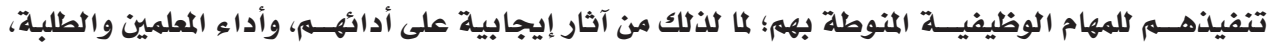

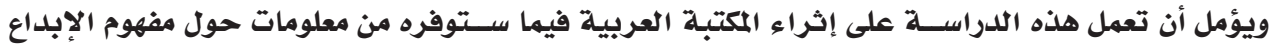

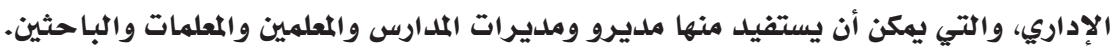

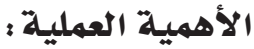

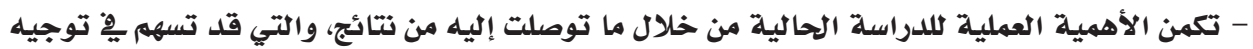

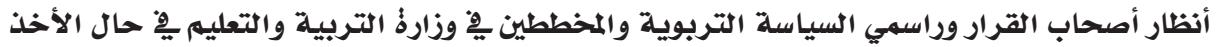

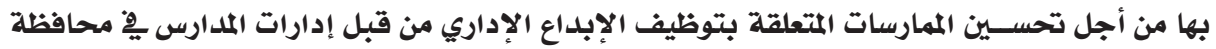

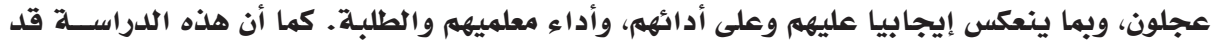

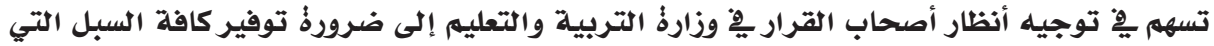

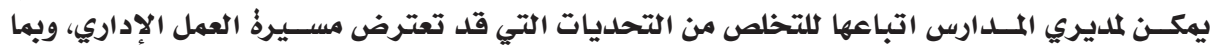
ينعكس على أدائهم وأداء المعلمين نحو عملها المها

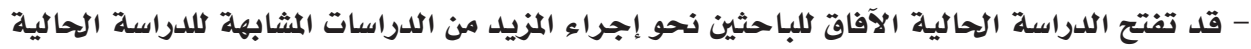

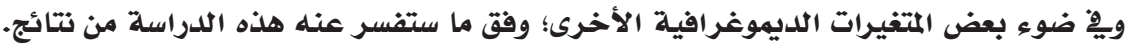

\section{مصطلحات الدراسة:}

شملت الدراسة على التعريفات الإجرائية والاصطلاحية الآتية ؛

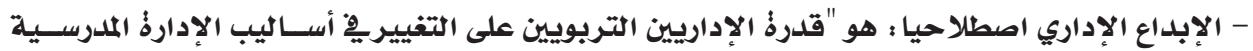

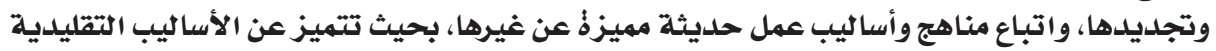

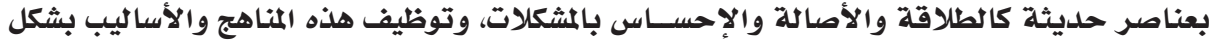

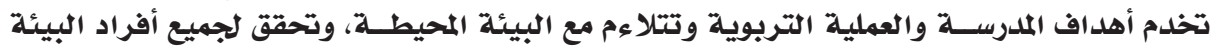

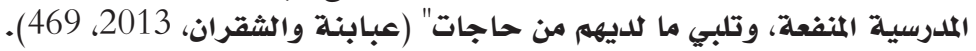

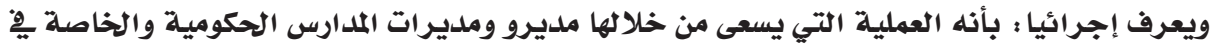

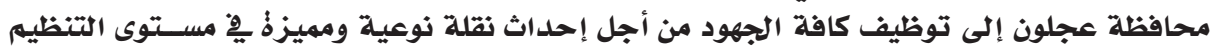

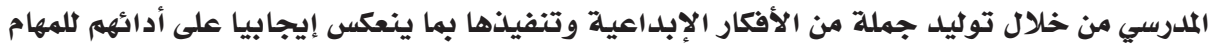

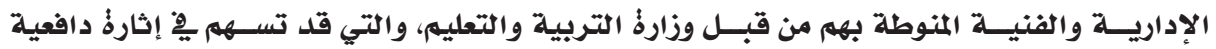

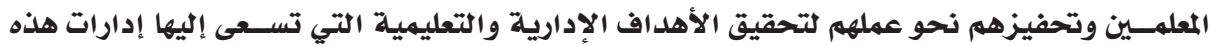

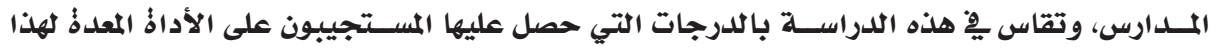
الغرض.

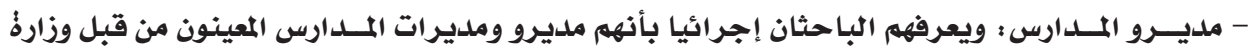

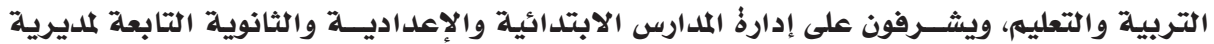

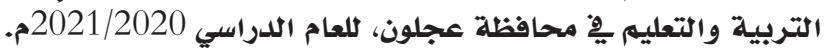




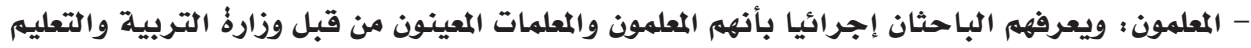

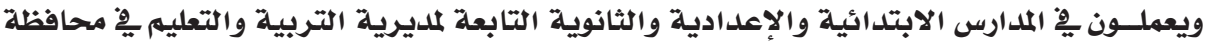

$$
\begin{aligned}
& \text { عجلون، للعام الدراسي 2021/2020م. } \\
& \text { حدود الدراسة ومحدد حداتها: } \\
& \text { وتتمثل حلدود الدراسة ومحدداتها فيما يأتي: }
\end{aligned}
$$

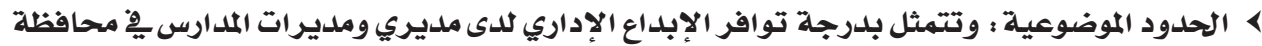

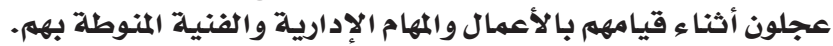

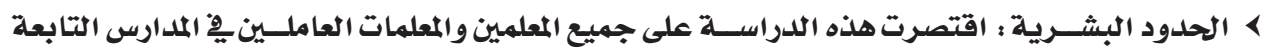

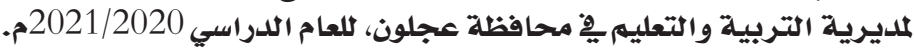

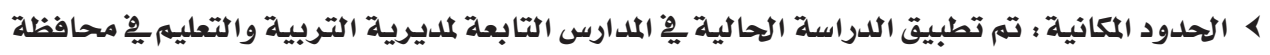
عجلون. > الحلدود الزمانية : تم تطبيق هذه الدراسة خلال الفصل الدراسي الأول للعام الدراسي 2021/2020م.

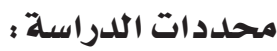

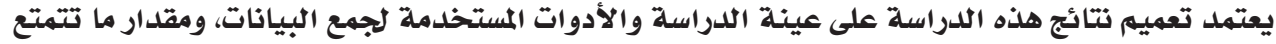

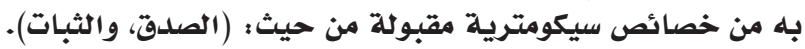

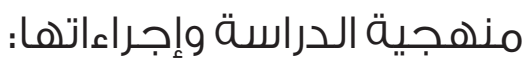
منهج الدراسلة : اعتمدت الدراسة على المنهج الوصفي المسحي لمناسبته لطبيعتها، وتحقيق أهلافها.

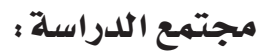

تكون مجتمع الدراسة من جميع المعلمين والمعلمات العاملين فِّ المدارس الحكومية والخاصة التابعة ملمديرية

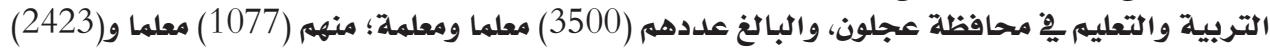

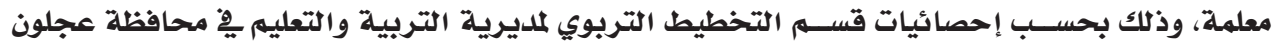

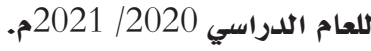
عينة الدراسلة :

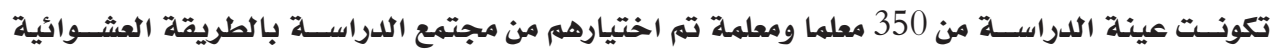

\begin{tabular}{|c|c|c|c|}
\hline النسبة المئوية & التكرار & مستويات/ فئات المتغير & المتغير \\
\hline 30.0 & 105 & ل & الجنس \\
\hline 70.0 & 245 & أنثى & \\
\hline 100.0 & 350 & المجموع الكلي & \\
\hline 55.1 & 193 & بكالوريوس & المؤهل العلمي \\
\hline 44.9 & 157 & دراسات عليا & \\
\hline 100.0 & 350 & المجموع الكلي & \\
\hline 52.6 & 184 & أساسية & المرحلة التعليمية \\
\hline 47.4 & 166 & ثانوية & \\
\hline 100.0 & 350 & المجموع الكلي & \\
\hline
\end{tabular}

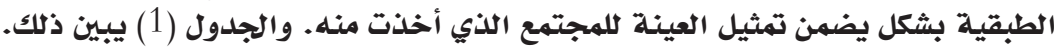

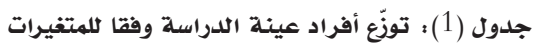


حسني أنعام سالم تغريل رضوان المومني

المجلد الثاني عشر العدد (22) 2021م ألمريد رضوان المومي

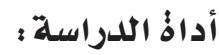

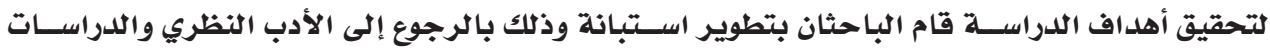

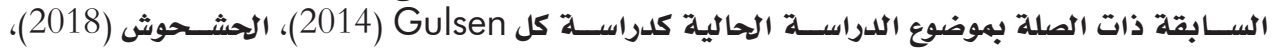

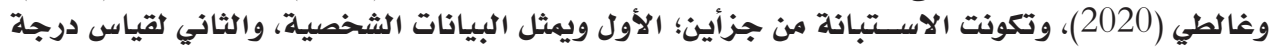

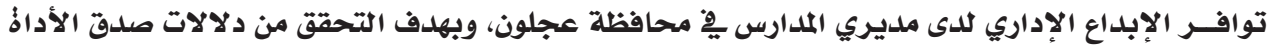

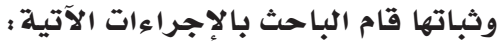

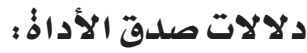

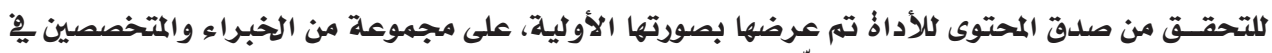

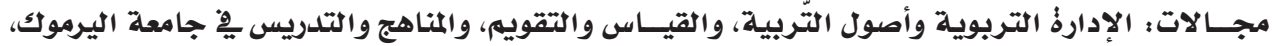

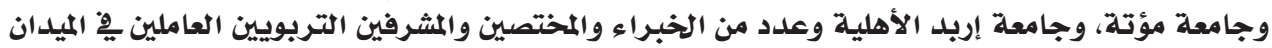

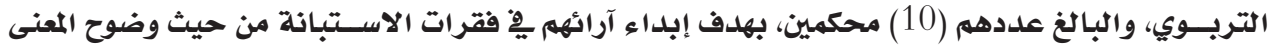

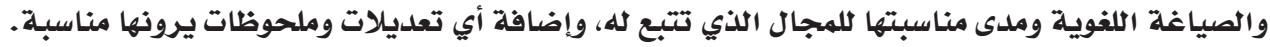
تم الأخذ بالملحوظات التي أجمع عليها ما نسبته أكثر من 80 \% من المحكمين، والتي اقتصرت على : إجراء ألماء

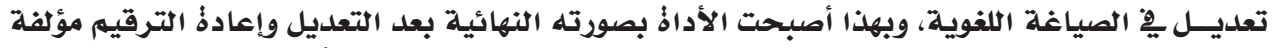

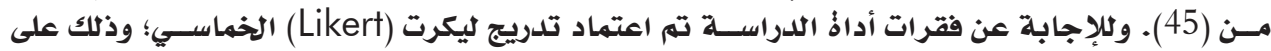

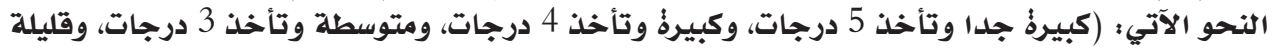

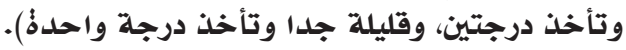

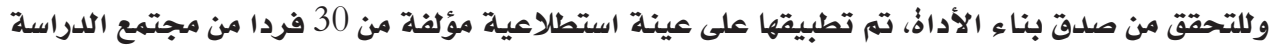

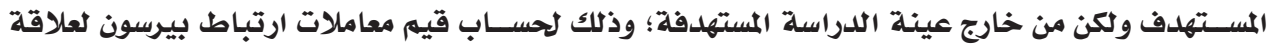

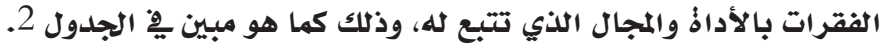

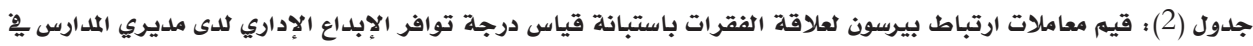
محافظة عجلون والمجال الذي تتبع له له

\begin{tabular}{|c|c|c|c|c|}
\hline \multicolumn{2}{|c|}{ معامل الارتباط بـ } & \multirow{2}{*}{ 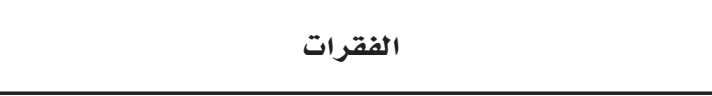 } & \multirow{2}{*}{ 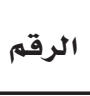 } & \multirow{2}{*}{ 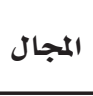 } \\
\hline 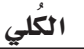 & المجالات & & & \\
\hline 0.67 & 0.43 & يقدم طرقا جديدة لتنفيذ الأعمال المتعلقة بالمدرسة. & 1 & الأصالة \\
\hline 0.45 & 0.66 & يوفر الأدوات التكنولوجية الحديثة لخدمة التعليم. & 2 & \\
\hline 0.56 & 0.40 & يساهم يِّ اقتراح أفكار جديدة: لتطوير الممارسات الإدارة ٍِِِ المدرسة. & 3 & \\
\hline 0.41 & 0.39 & يساعد المعلمين على ابتكار أفكار خلاقة لتطوير العملية التعليمية. & 4 & \\
\hline 0.59 & 0.29 & يبتكر آليات مبتكرةٌ للتعامل مع المشكلات التي تتعرض لها المدرسة. & 5 & \\
\hline 0.37 & 0.66 & يوظف أدوات تكنولوجيا المعلومات والاتصالات بِّ مجال تطوير العمل & 6 & \\
\hline 0.51 & 0.25 & يمتلك المقدرة على إنتاج أفكار جديدةٌ لم يسبق أن تطرق إليها أحد. & 7 & \\
\hline 0.57 & 0.65 & يضع حلول مميزةٌ وفريدة للقضايا والمشكلات التربوية المطروحة. & 8 & \\
\hline 0.57 & 0.60 & يقدم الحلول للأحداث والمواقف والقضايا والمشكلات المستعصية بمنظور & 9 & \\
\hline 0.51 & 0.57 & يتابع بجد جميع الأحداث الجارية والتطورات يِّ مجال العمل الإداري. & 10 & \\
\hline 0.62 & 0.44 & يبتعد عن الشائع من الأفكار التقليدية عند التعامل مع المواقف غير & 11 & \\
\hline 0.54 & 0.24 & يستثمر ساعات الدوام من أجل إنجاز الإعمال بكفاءة. & 12 & \\
\hline
\end{tabular}




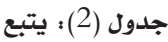

\begin{tabular}{|c|c|c|c|c|}
\hline \multicolumn{2}{|c|}{ معامل الارتباط بـ } & \multirow{2}{*}{ الفقرات } & \multirow{2}{*}{ الرقم } & \multirow{2}{*}{ 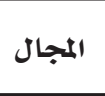 } \\
\hline التُلي & المجالات & & & \\
\hline 0.64 & 0.55 & يعطي أحكام موضوعية محلددة بِِ المواضيع الفنية والإدارية. & 13 & الطلاقة \\
\hline 0.62 & 0.36 & يطرح أسئلة ذات إجابات مفتوحة النهاية حول المشكلات المطرحة. & 14 & \\
\hline 0.63 & 0.60 & يستخلص أكبر عدد ممكن من النتائج المحتملة للقضايا والمشكلات & 15 & \\
\hline 0.58 & 0.30 & يتجاوز العقبات التي تعترض تحقيق الأهداف بمختلف الوسائل الممكنة. & 16 & \\
\hline 0.70 & 0.59 & يشجع المعلمين على المناقشة والحوار لحل المشكلات التريوية والتعليمية. & 17 & \\
\hline 0.53 & 0.29 & يطور علاقاته مع المهنيين الذين يعملون بِّ المدارس الأخرى لخدمة & 18 & \\
\hline 0.57 & 0.59 & يدير النقاش والحوار مع المعلمين بطريقة فاعلة. & 19 & \\
\hline 0.50 & 0.45 & يقدم أكثر من فكرةٌ خلال مدةُ قصيرة. & 20 & \\
\hline 0.38 & 0.50 & يُعبر عن أفكاره بطلاقة. & 21 & \\
\hline 0.40 & 0.50 & يمتاز بسرعة البديهة يِّ التصرف يِّ الأزمات. & 22 & \\
\hline 0.62 & 0.47 & يتنبأ بالمتغيرات التي تحصل ِِّ البيئة الخارجية لججاراتها. & 23 & 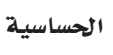 \\
\hline 0.58 & 0.52 & يتمكن من رؤية التهديدات المؤثرةٌ على البيئة التعليمية. & 24 & 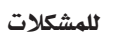 \\
\hline 0.61 & 0.47 & يتنبأ بمشكلات العمل قبل وقوعها. & 25 & \\
\hline 0.63 & 0.60 & يتوقع المشكلات التي يعاني منها المعلمين والعاملين يِّ المدرسة. & 26 & \\
\hline 0.61 & 0.57 & يتنباً بقدرات وإمكانيات المعلمين والعاملين يِّ المدرسة. & 27 & \\
\hline 0.55 & 0.52 & يحدد جوانب المشكلات التعليمية والتربوية المختلفة. & 28 & \\
\hline 0.62 & 0.42 & يعد خطة خاصة لمواجهة العقبات التي تعترض العمل & 29 & \\
\hline 0.56 & 0.69 & يبحث عن بدائل جديدة لحل المشكلات بدلا من الحلول المعتادة. & 30 & \\
\hline 0.54 & 0.35 & يكثر من طرح الأسئلة عن أسباب المشكلات. & 31 & \\
\hline 0.44 & 0.51 & يتعامل بصبر مع المشكلات التي تواجهه & 32 & \\
\hline 0.64 & 0.35 & يرتب المشكلات حسب أهميتها يِ أولوية الحلول. & 33 & \\
\hline 0.22 & 0.51 & يكافئ المعلمين المتميزين بِّ المدرسة على هِ المحافل المختلفة. & 34 & \\
\hline 0.28 & 0.48 & يهيئ نفسه بأساليب متنوعة لأي نقد يوجه إليه & 35 & 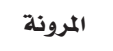 \\
\hline 0.36 & 0.27 & يحصل على المعارف والمعلومات من مصادرها بطرق عديدةٌ ومتنوعة. & 36 & \\
\hline 0.45 & 0.40 & يقدم أفكار متنوعة حول القضايا والأحداث والمشكلات المطروحة. & 37 & \\
\hline 0.60 & 0.53 & يسترشد بآراء الآخرين قبل تحديد الأهداف & 38 & \\
\hline 0.62 & 0.33 & يستخدم منهجية التفكير العلمي يِّ حل المشكلات & 39 & \\
\hline 0.54 & 0.29 & يبني علاقات إنسانية مع المعلمين والطلبة. & 40 & \\
\hline 0.64 & 0.41 & يتقبل الأفكار الجديدةٌ بكل موضوعية. & 41 & \\
\hline 0.62 & 0.34 & يتقبل الأفكار والمقترحات من المعلمين والعاملين يْ المدرسة حتى وإن كانت & 42 & \\
\hline 0.63 & 0.59 & يحلل الموقف من زوايا مختلفة. & 43 & \\
\hline 0.58 & 0.48 & يتقبل النقد البناء من المعلمين والعاملين بِّ المدرسة بهدف الارتقاء & 44 & \\
\hline 0.70 & 0.40 & يتكيف مع المواقف المختلفة باحترافية عالية. & 45 & \\
\hline
\end{tabular}

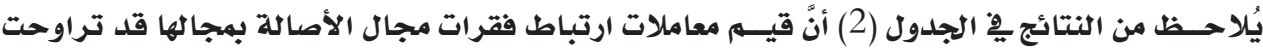

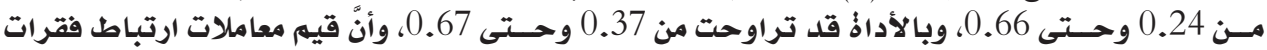




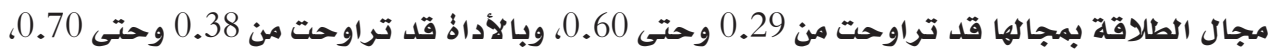

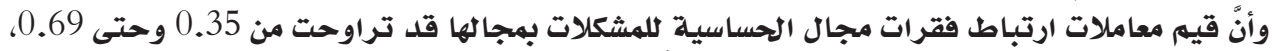

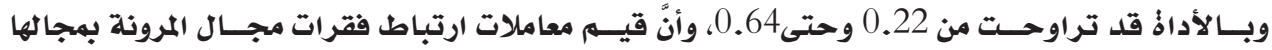

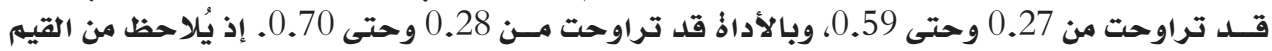

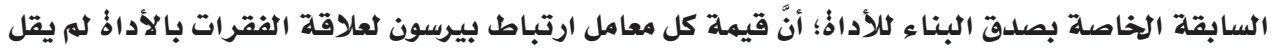

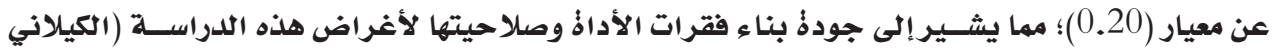
والشريفين، 2011، 431).

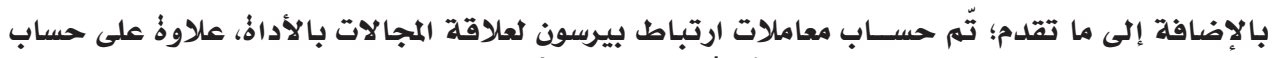

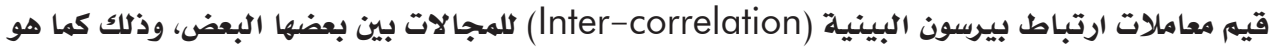

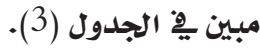
جلدول (3) : قيم معاملات ارتباط بيرسون لعلاقة المجالات بالأداف، وقيه معاملات ارتباط بيرسون البينية للهجالات بين بعضها البعض

\begin{tabular}{|c|c|c|c|c|c|}
\hline المرونة & الحساسية للمشكلات & الطلاقة & الأصالة & الإحصائي & العلاقة \\
\hline & & & 0.76 & معامل الارتباط & الطلاقة \\
\hline & & & 0.00 & الدلالة الإحصائية & \\
\hline & & 0.81 & 0.72 & معامل الارتباط & الحساسية \\
\hline & & 0.00 & 0.00 & الدلالة الإحصائية & ل للمشكلات \\
\hline & 0.67 & 0.87 & 0.67 & معامل الارتباط & المرونة المرو \\
\hline & 0.00 & 0.00 & 0.00 & الدلالة الإحصائية & \\
\hline 0.89 & 0.89 & 0.96 & 0.87 & معامل الارتباط & الكُلي \\
\hline 0.00 & 0.00 & 0.00 & 0.00 & الدلالة الإحصائية & للمقياس \\
\hline
\end{tabular}

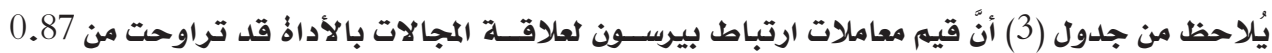

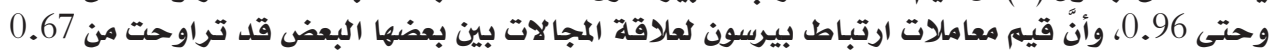

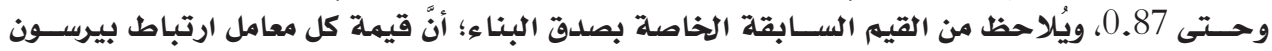

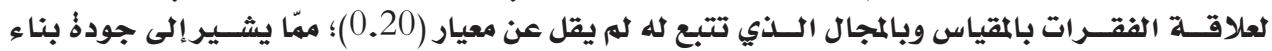

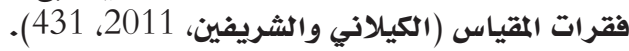

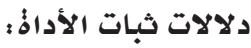

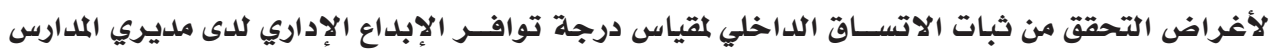

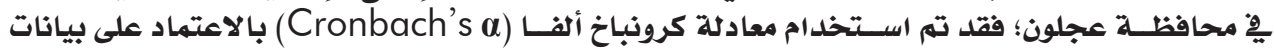

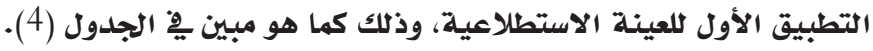
جدول (4): قيم معاملات ثبات الاتساق الداخلي لمقياس درجة توافر الإبداع الإداري لدى مديري المدارس ومجالاته

\begin{tabular}{|c|c|c|}
\hline عدد الفقرات & ثبات الاتساق الداخلي & المقياس ومجالاته \\
\hline 12 & 0.96 & الأصالة \\
\hline 10 & 0.93 & الطلاقة \\
\hline 12 & 0.95 & الحساسية للهشكلات \\
\hline 11 & 0.95 & 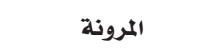 \\
\hline 45 & 0.92 & الكُلي للمقياس \\
\hline
\end{tabular}

يُلاحظ من جلدول (4) أنَّ قيمة ثبات الاتسـاق الداخلي لمقياس درجلة توافر الإبداع الإداري للدى مديري

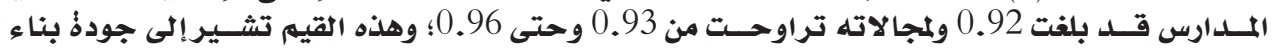
المقياس وصلاحيته لأغراض هذه الدراسة (الكيلاني والشريفين، 2011، 
المعيار المعتمد يْ الحكم على المتوسطات الحسابية ؛

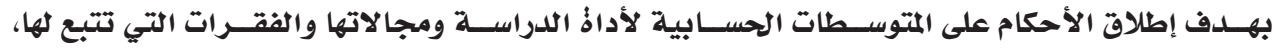

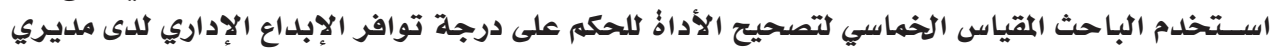

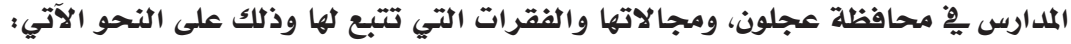

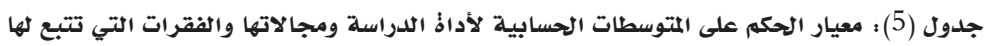

\begin{tabular}{|c|c|}
\hline فئة المتوسطات الحسابية & الدرجة \\
\hline من 5.2 - & كبيرةٌ جدا \\
\hline من 3.4 - أقل من 4.2 & 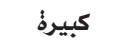 \\
\hline من 2.6 - أقل من 3.4 & 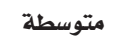 \\
\hline من -1.8 أقل من 2.6 & قليلة \\
\hline من -1.0 أقل من 1.8 & قليلة جدا \\
\hline
\end{tabular}

متغيرات الدراسة : الدئة

اشتملت الدراسة على المتغيرات الآتية :

أولا: المتغيرات المستقلة وتشمل:

- الجنس، وله فئتان : (ذكر، أنثى).

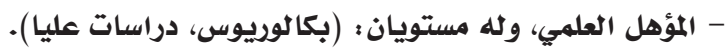

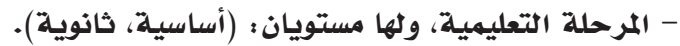

ثانيا : المتفير التابع، ويشمل :

- تقديرات أفراد العينة لدرجة توافر الإبداع الإداري لدى مديري المدارس مِّه محافظة عجلون.

$$
\begin{aligned}
& \text { إجراءات الدراسلة : } \\
& \text { قام الباحثان بالإجراءات الآتية ؛ }
\end{aligned}
$$

- الاطلاع على الأدب التربوي، والدراءئات الات الاتية السابقة ذات الصلة بموضوع الدراسة الحالية.

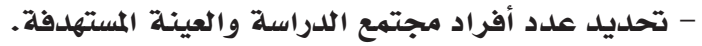

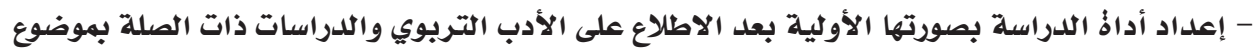

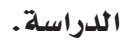

- التحقق من دلالات صدق أداذٌ الدراسة وثباتها للخروج بالصورةٌ النهائية للأداثُ.

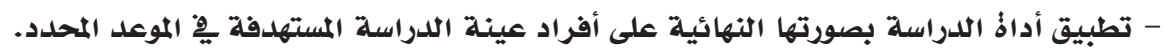

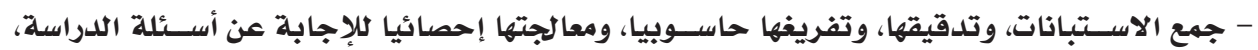

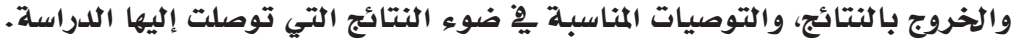

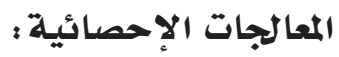

لتنفيذ الدراسلة والإجابة عن أسئلتها، تم استخدام المعالجات الإحصائية الآتية ؛

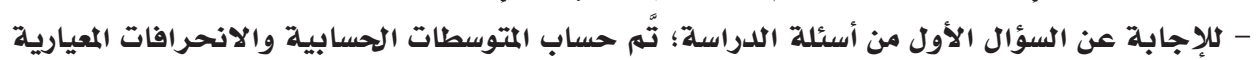

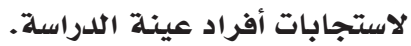

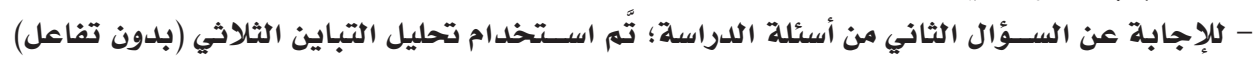

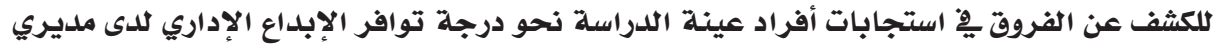
المدارس يٌْ محافظة عجلون. 
حسني أنعام سالم تغريل رضوان المومني

المجلد الثاني عشر العدد (22) 2021م ألمريد رضوان المومي

نتائج الدراسة ومناقشتها:

هدفت الدراســة إلى الكثـف عن درجة توافر الإبلداع الإداري لدى ملديري المدارس يْ محافظة عجلون،

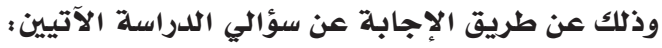

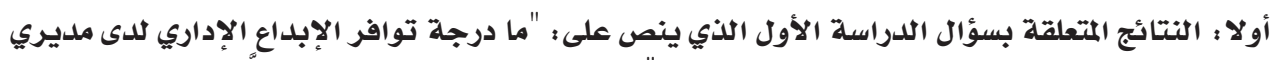

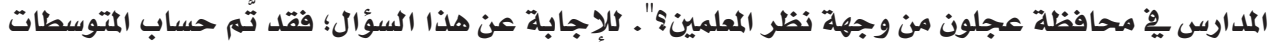

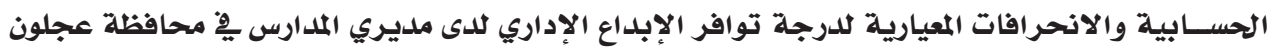

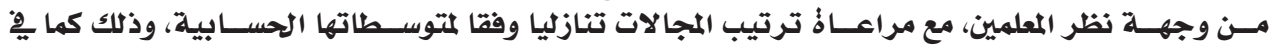

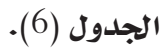

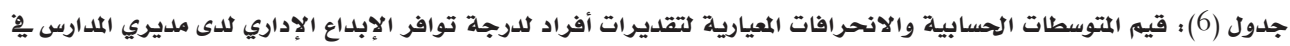

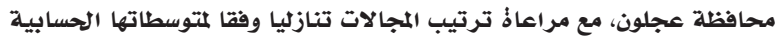

\begin{tabular}{|c|c|c|c|c|c|}
\hline الدرجة & الانحراف المعياري & المتوسط الحسابي & المقياس ومجالاته & رقم المجال & الرتبة \\
\hline كبيرة؛ & 0.92 & 3.67 & الطلاقة & 2 & 1 \\
\hline كبيرة & 0.94 & 3.59 & المرونة المرن & 4 & 2 \\
\hline كبيرة & 0.95 & 3.46 & الحساسية للمشكلات & 3 & 3 \\
\hline كبيرة: & 0.92 & 3.45 & الأصالة & 1 & 4 \\
\hline كبيرة: & 0.88 & 3.54 & الكُلي للمقياس & & \\
\hline
\end{tabular}

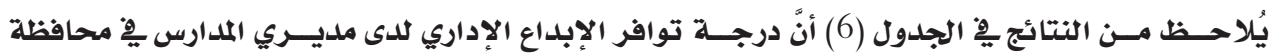

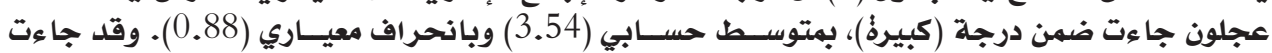

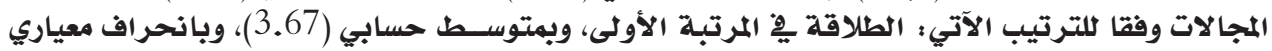

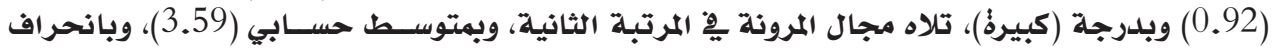

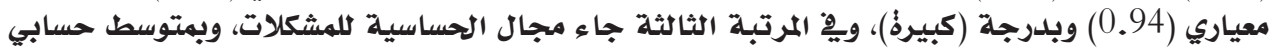

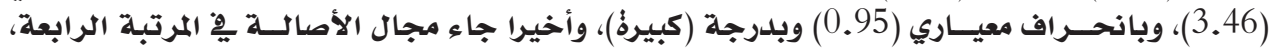
وبمتوسط حسابي (3.45)، وبانحراف معياري (0.92)، (0.92)، وبلدرجة واخيران (كبيرة).

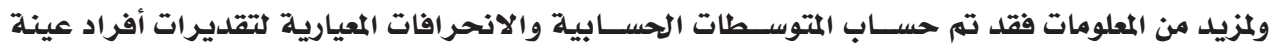

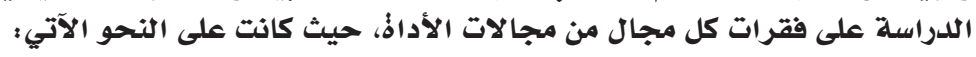

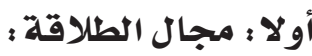

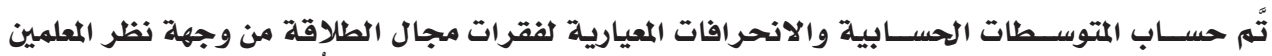

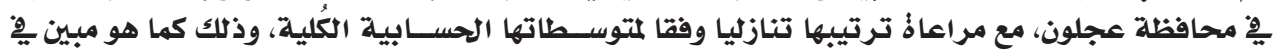
الجدول (7).

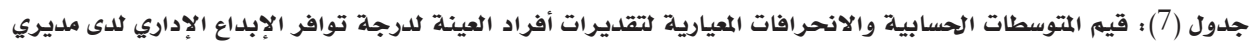

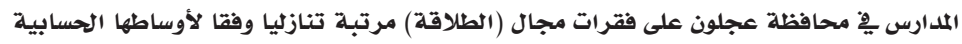

\begin{tabular}{|c|c|c|c|c|c|}
\hline الدرجة & الانحراف & المتوسطابي & الفقرات & 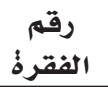 & الرتبة \\
\hline كبيرة & 1.45 & 3.98 & يشجع المعلمين على المناقشة والحوار لحل المشكلات التربوية & 17 & 1 \\
\hline كبيرة & 1.61 & 3.69 & يتجاوز العقبات التي تعترض تحقيق الأهداف بمختلف المكنة. & 16 & 2 \\
\hline 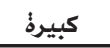 & 1.50 & 3.55 & يمتاز بسرعة البديهة ٍِِ التصرف هٍِ الأزمات. & 22 & 3 \\
\hline
\end{tabular}


جدول (7) : يتبع

\begin{tabular}{|c|c|c|c|c|c|}
\hline الدرجة & الانحياري & الحسابي & 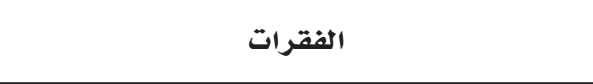 & الفقرة & الرتبة \\
\hline كبيرة & 1.53 & 3.42 & يُعبر عن أفكاره بطلاقة. & 21 & $\overline{4}$ \\
\hline متوسطة & 1.40 & 3.36 & يطور علاقاته مع المهنيين الذين يعملون بِّ المدارس الأخرى & 18 & 5 \\
\hline متوسطة & 1.49 & 3.35 & يدير النقاش والحوار مع المعلمين بطريقة فاعلة. & 19 & 6 \\
\hline متوسطة & 1.53 & 3.33 & يقدم أكثر من فكرة خلال مدةُ قصيرة. & 20 & 7 \\
\hline متوسطة & 1.60 & 3.31 & يستخلص أكبر عدد ممكن من النتائج المحتملة للقضايا & 15 & 8 \\
\hline متوسطة & 1.63 & 3.29 & يطرح أسئلة ذات إجابات مفتوحة النهاية حول المشكلات & 14 & 9 \\
\hline متوسطة & 1.64 & 3.28 & يعطي أحكام موضوعية محددة بِّإ المواضيع الفنية & 13 & 10 \\
\hline 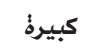 & 0.95 & 3.46 & الكُلي للمجال & & \\
\hline
\end{tabular}

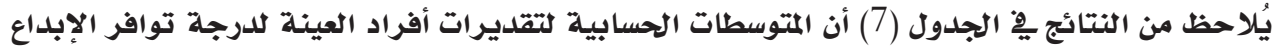

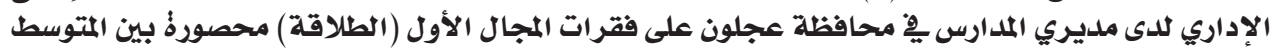

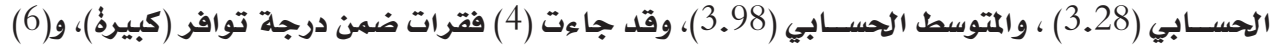

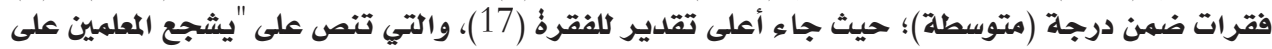

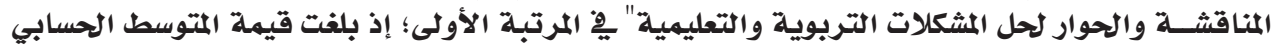

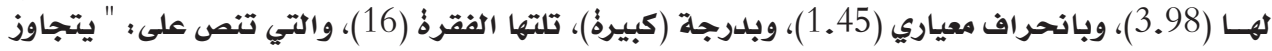

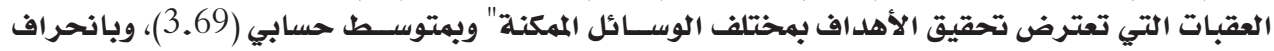

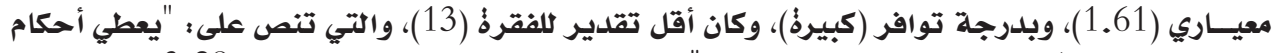

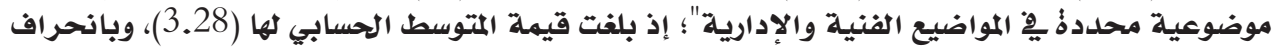
معياري (1.64)، وبدرجة مدورة (متوسطة).

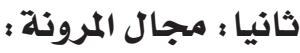

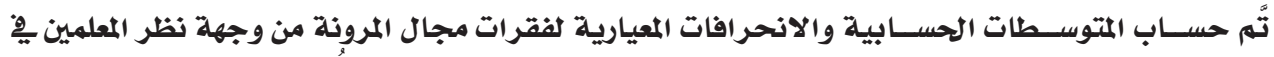

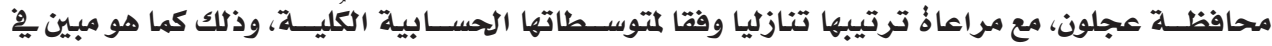

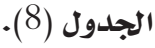

جلدول (8): قيم المتوسطات الحسابية والانحرافات المعيارية لتقديرات أفراد العينة لدرجة توافر الإبلاع الإداري لدى ملديري

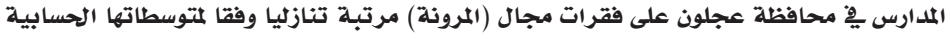

\begin{tabular}{|c|c|c|c|c|c|}
\hline الدرجة & الانحراف & المتوسطابي & الفقرات & الفقرة: & الرتبـة \\
\hline كبيرة & 1.40 & 4.05 & يحصل على المعارف والمعلومات من مصادرها بطرق عديدة. & 36 & 1 \\
\hline كبيرة & 1.38 & 4.02 & يقدم أفكار متنوعة حول القضايا والأحداث والمشكلات & 37 & 2 \\
\hline كبيرة: - ت & 1.45 & 4.00 & يسترشد بآراء الآخرين قبل تحديد الأهداف & 38 & 3 \\
\hline 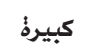 & 1.45 & 3.98 & يتكيف مع المواقف المختلفة باحترافية عالية. & 45 & 4 \\
\hline 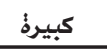 & 1.39 & 3.94 & يهيئ نفسه بأساليب متنوعة لأي نقد يوجه إليه & 35 & 5 \\
\hline
\end{tabular}


حسني أنعام سالم تغريل رضوان المومني

المجلد الثاني عشر العدد (22) 2021م تفريل رضوان المغني

جدول (8) :يتبع

\begin{tabular}{|c|c|c|c|c|c|}
\hline الدرجة & الانحراف & المتوسطابي & الفقرات & 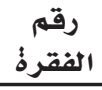 & الرتبـة \\
\hline 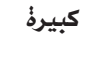 & 1.61 & 3.69 & 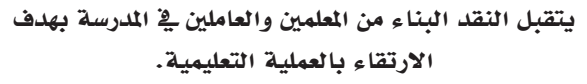 & 44 & 6 \\
\hline 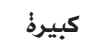 & 1.57 & 3.43 & يبني علاقات إنسانية مع المعلمين والطلبة. & 40 & 7 \\
\hline كبيرة: - اء & 1.53 & 3.41 & يستخدم منهجية التفكير العلمي يِّ حل المشكلات & 39 & 8 \\
\hline متوسطة & 1.60 & 3.31 & يحلل الموقف من زوايا مختلفة. & 43 & 9 \\
\hline متوسطة & 1.63 & 3.29 & يتقبل الأفكار والمقترحات من المعلمين والعاملين بِّ المدرسة & 42 & 10 \\
\hline متوسطة & 1.64 & 3.28 & يتقبل الأفكار الجديدة بكل موضوعية. & 41 & 11 \\
\hline كبيرة اء & 0.92 & 3.67 & الكُلي للمجال & & \\
\hline
\end{tabular}

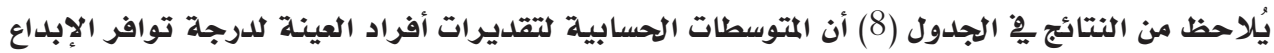

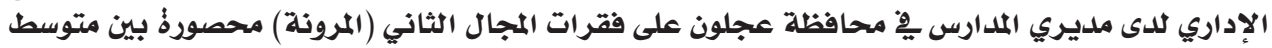

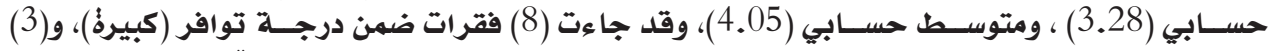

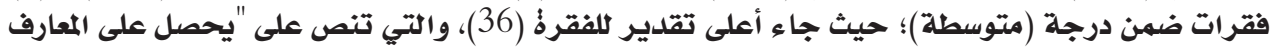

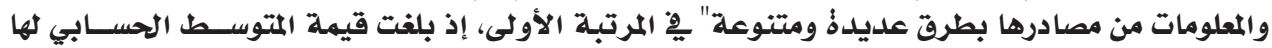

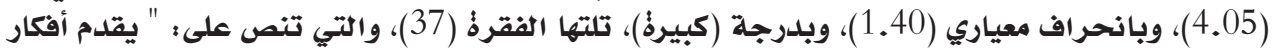

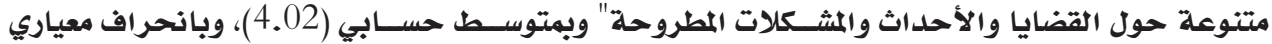

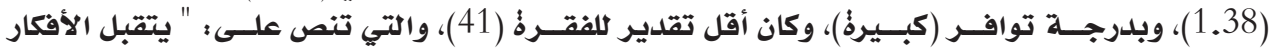

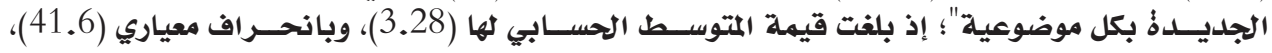

وبلدرجة (متوسطة).

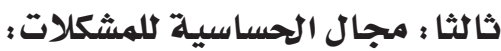

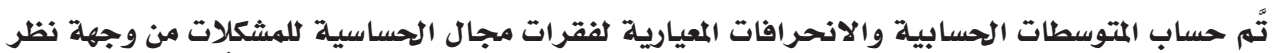

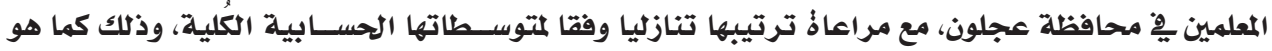

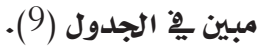

جدول (9) : قيم المتوسطات الحسابية والانحرافات المعيارية لتقديرات أفراد العينة لدرجة توافر الإبداع الإداري لدى مداريري

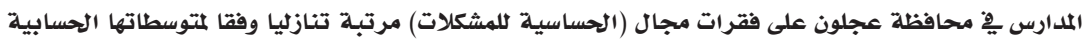

\begin{tabular}{|c|c|c|c|c|c|}
\hline الدرجة & الانحراف & المتوسطابي & الفقرات & الفقرة & الرتبـة \\
\hline كبيرة & 1.39 & 4.05 & يتعامل بصبر مع المشكلات التي تواجهه & 32 & 1 \\
\hline كبيرة & 1.56 & 3.85 & يرتب المشكلات حسب أهميتها يِّ أولوية الحلول. & 33 & 2 \\
\hline 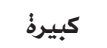 & 1.38 & 3.77 & يكافئ المعلمين المتميزين بِِ المدرسة على ِِّ المحافل المختلفة. & 34 & 3 \\
\hline كبيرة & 1.53 & 3.66 & يكثر من طرح الأسئلة عن أسباب المشكلات. & 31 & 4 \\
\hline كبيرة & 1.49 & 3.63 & يبحث عن بدائل جديدةُ لحل المشكلات بدلا من الحلول & 30 & 5 \\
\hline كبيرة & 1.50 & 3.57 & يتنبأ بقدرات وإمكانيات المعلمين والعاملين يِّ المدرسة. & 27 & 6 \\
\hline كبيرة & 1.52 & 3.53 & يعد خطة خاصة لمواجهة العقبات التي تعترض العمل & 29 & 7 \\
\hline 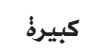 & 1.47 & 3.51 & يحدد جوانب المشكلات التعليمية والتربوية المختلفة. & 28 & 8 \\
\hline 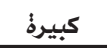 & 1.57 & 3.43 & يتنبأ بمشكلات العمل قبل وقوعها. & 25 & 9 \\
\hline
\end{tabular}




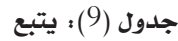

\begin{tabular}{|c|c|c|c|c|c|}
\hline الدرجة & الانحياري & الحتوسط ابي & الفقرات & الفقرة: & الرتبـة \\
\hline كبيرة & 1.53 & 3.40 & يتوقع المشكلات التي يعاني منها المعلمين والعاملين ٍِِ المدرسة. & 26 & 10 \\
\hline كبيرة & 1.62 & 3.40 & يتمكن من رؤية التهديدات المؤثرةٌ على البيئة التعليمية. & 24 & 11 \\
\hline متوسطة & 1.55 & 3.27 & يتنبأ بالمتغيرات التي تحصل ٍِِ البيئة الخارجية لمجاراتها. & 23 & 12 \\
\hline كبيرة اء & 0.94 & 3.59 & الكُلي للمجال & & \\
\hline
\end{tabular}

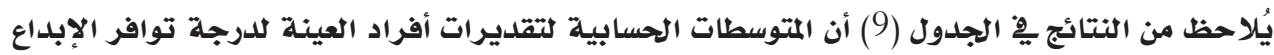

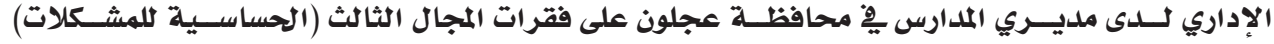

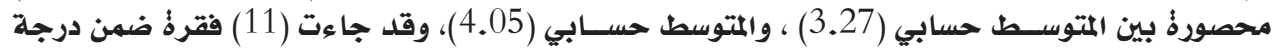

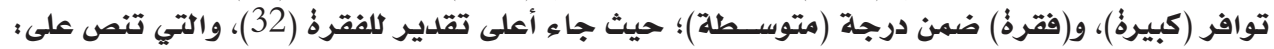

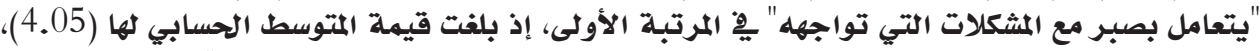

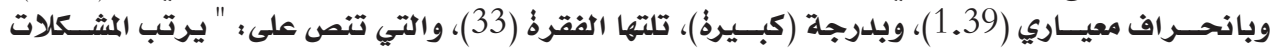

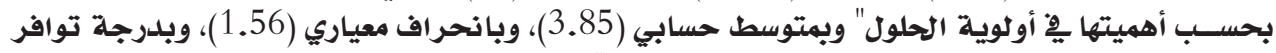

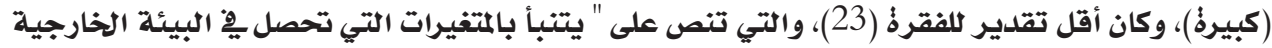

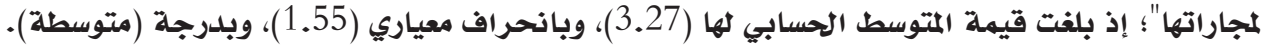

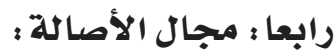

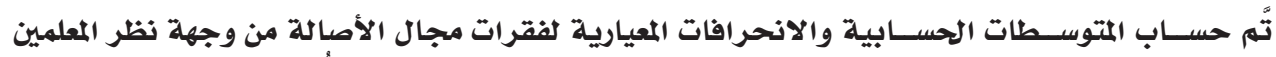

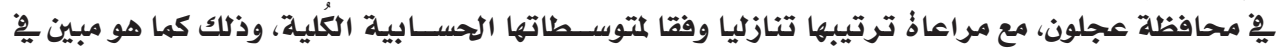
الجدول (10).

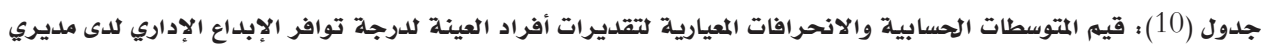

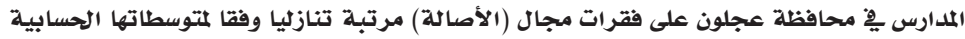

\begin{tabular}{|c|c|c|c|c|c|}
\hline 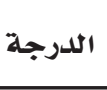 & الانحراف & المتوسطابي & الفقرات & الفقرة: & الرتبـة - الر \\
\hline كبيرة & 1.46 & 3.70 & يساعد المعلمين على ابتكار أفكار خلاقة لتطوير العملية & 4 & 1 \\
\hline كبيرة اذ & 1.57 & 3.63 & يقدم طرقا جديدةُ لتنفيذ الأعمال المتعلقة بالمدرسة. & 1 & 2 \\
\hline كبيرة & 1.48 & 3.58 & يوظف أدوات تكنولوجيا المعلومات والاتصالات ِِّ مجال & 6 & 3 \\
\hline 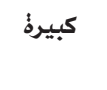 & 1.46 & 3.58 & يمتلك المقدرة: على إنتاج أفكار جديدة: لم يسبق أن تطرق & 7 & 4 \\
\hline 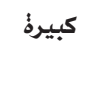 & 1.52 & 3.53 & يقدم الحلول للأحداث والمواقف والقضايا والمشكلات & 9 & 5 \\
\hline كبيرة & 1.54 & 3.45 & يتابع بجد جميع الأحداث الجارية والتطورات فِّمال مجال & 10 & 6 \\
\hline كبيرة & 1.57 & 3.43 & يستثمر ساعات الدوام من أجل إنجاز الإعمال بكفاءة. & 12 & 7 \\
\hline كبيرة اء & 1.43 & 3.43 & يوفر الأدوات التكنولوجية الحديثة لخدمة التعليه. & 2 & 8 \\
\hline 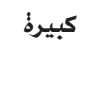 & 1.53 & 3.41 & يبتعد عن الشائع من الأفكار التقليدية عند التعامل مع المواقف & 11 & 9 \\
\hline متوسطة & 1.60 & 3.29 & 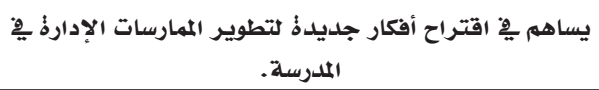 & 3 & 10 \\
\hline
\end{tabular}


جدول (10) : يتبع

\begin{tabular}{|c|c|c|c|c|c|}
\hline الدرجة & الانحراف & الحتوسطابي & الفقرات & 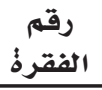 & الرتبـة \\
\hline متوسطة & 1.57 & 3.24 & يضع حلول مميزةٌ وفريدةُ للقضايا والمشكلات التربوية & 8 & 11 \\
\hline متوسطة & 1.70 & 3.18 & يبتكر آليات مبتكرة: للتعامل مع المشكلات التي تتعرض لها & 5 & 12 \\
\hline كبيرة & 0.92 & 3.45 & الكُلي للمجال & & \\
\hline
\end{tabular}

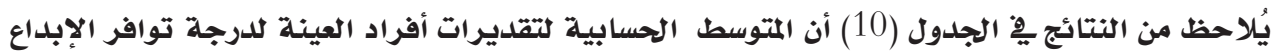

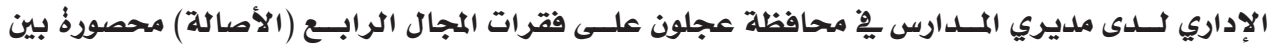

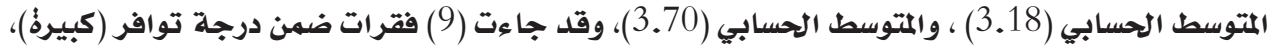

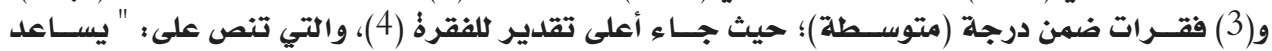

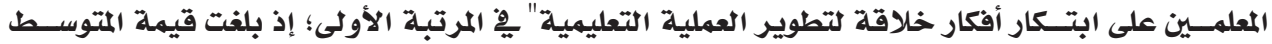

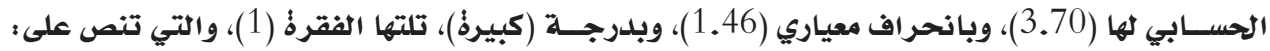

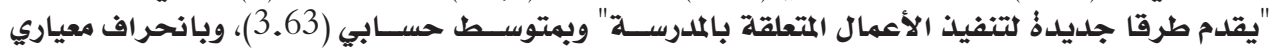

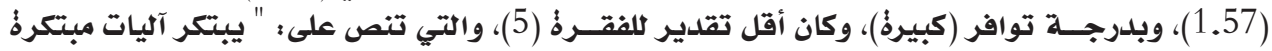

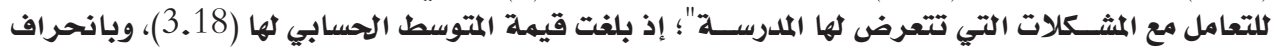
معياري (1.70)، وبلدرجة (متلامت الثتوسطة).

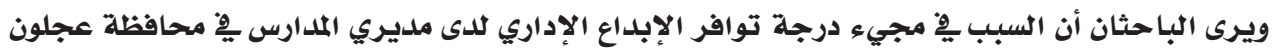

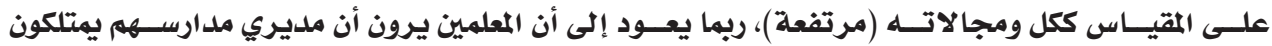

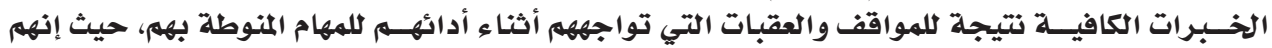

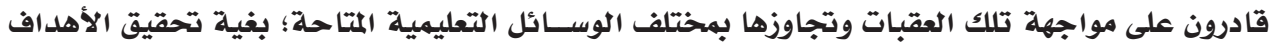

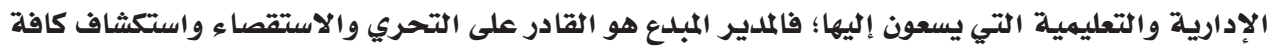

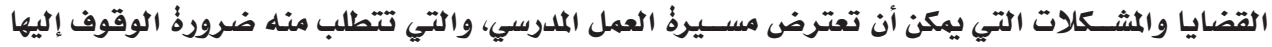

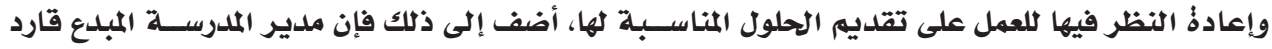

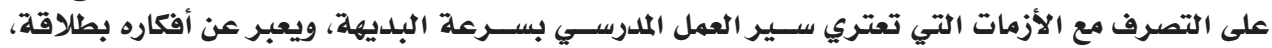

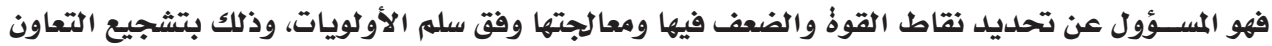

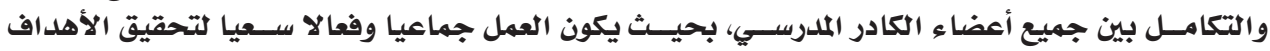
الإدارية والتعليمية للمدرسية.

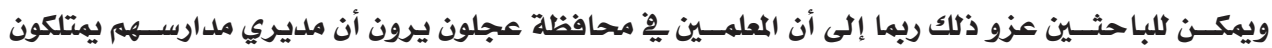

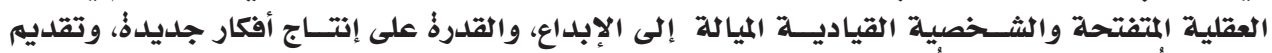

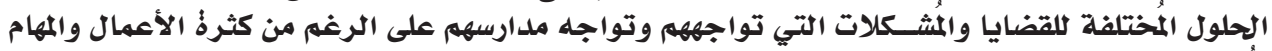

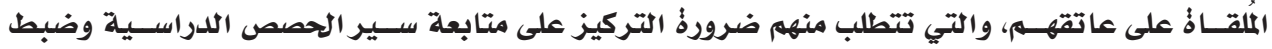

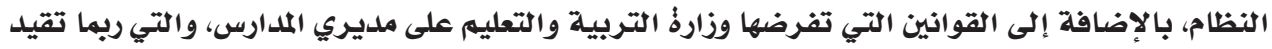

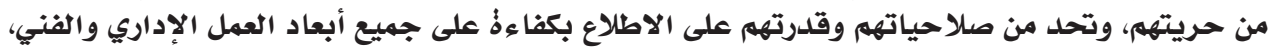

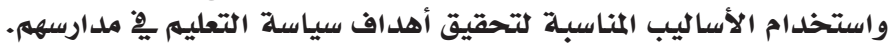

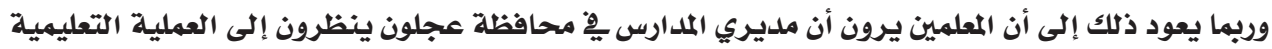

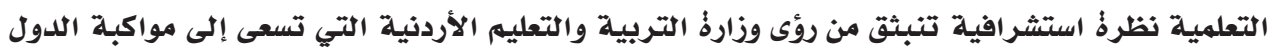

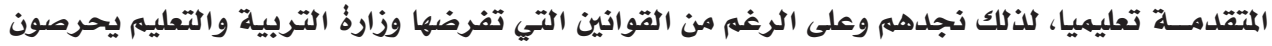

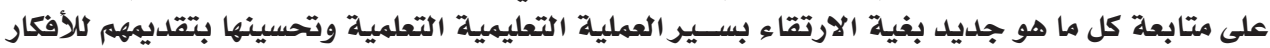

الإبلاعية التي تسهم هِّ تحسين بيئة المدرسة التعليمية، وتحفيز المعلمين على أداء مهامهم الوظيفية التهاية. 


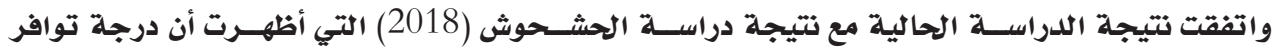

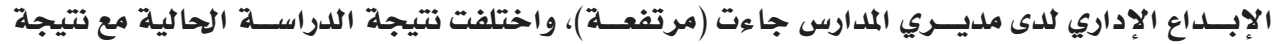

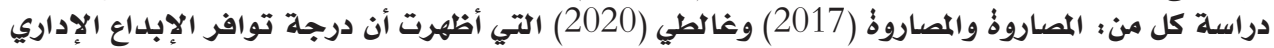

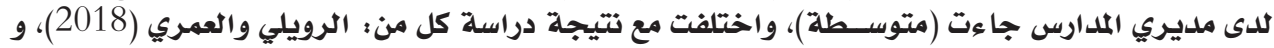

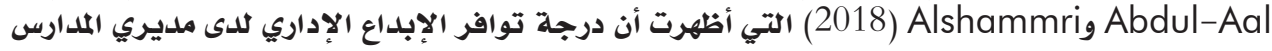

جاءت (منخفضة).

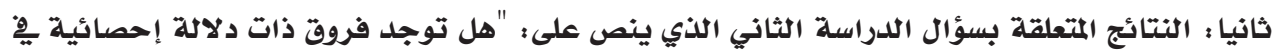

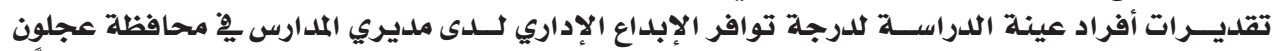

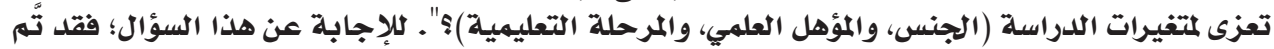

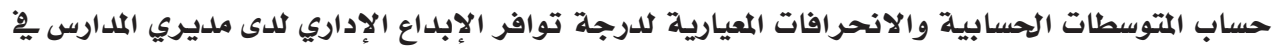

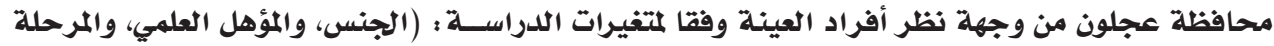

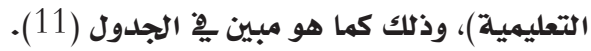

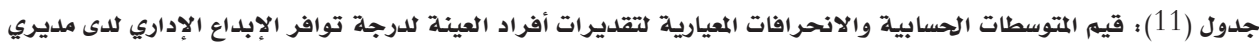

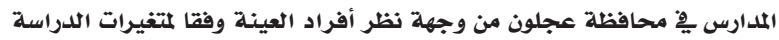

\begin{tabular}{|c|c|c|c|c|c|c|c|}
\hline \multirow{2}{*}{ للمقياسلي الكُّي } & \multicolumn{4}{|c|}{ المجالات } & \multirow[b]{2}{*}{ الإحصائي } & \multirow{2}{*}{ فئات المتتغير } & \multirow[b]{2}{*}{ المتغير } \\
\hline & المرونة & اللمشكاسلية & الطلاقة & الأصالة & & & \\
\hline 3.40 & 3.53 & 3.44 & 3.31 & 3.31 & المتوسط الحسابي & ذكر & الجنس \\
\hline 0.68 & 0.71 & 0.76 & 0.81 & 0.76 & الانحراف المعياري & & \\
\hline 3.61 & 3.73 & 3.65 & 3.52 & 3.52 & المتوسط الحسابي & أنثى & \\
\hline 0.94 & 0.99 & 1.00 & 0.99 & 0.98 & الانحراف المعياري & & \\
\hline 3.43 & 3.54 & 3.45 & 3.35 & 3.39 & المتوسط الحسابي & بكالوريوس & المؤهل \\
\hline 0.84 & 0.86 & 0.92 & 0.91 & 0.91 & الانحراف المعياري & & العلمي \\
\hline 3.68 & 3.84 & 3.76 & 3.59 & 3.53 & المتوسط الحسابي & دراسات عليا & \\
\hline 0.90 & 0.96 & 0.93 & 0.97 & 0.94 & الانحراف المعياري & & \\
\hline 3.44 & 3.55 & 3.45 & 3.37 & 3.39 & المتوسط الحسابي & أساسية & المرحلة \\
\hline 0.76 & 0.80 & 0.84 & 0.84 & 0.84 & الانحراف المعياري & & التعليمية \\
\hline 3.65 & 3.81 & 3.74 & 3.55 & 3.53 & المتوسط الحسابي & ثانوية & \\
\hline 0.98 & 1.02 & 1.02 & 1.04 & 1.01 & الانحراف المعياري & & \\
\hline
\end{tabular}

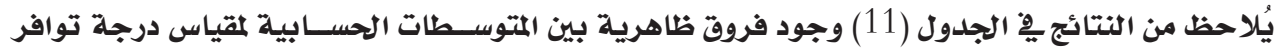

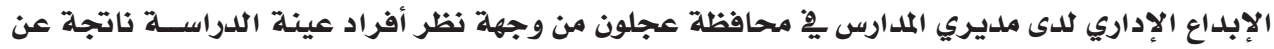

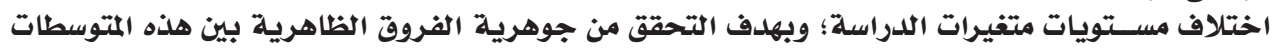

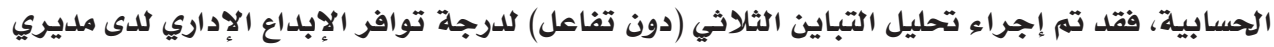

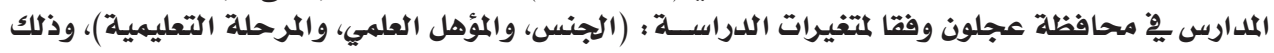

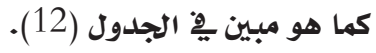

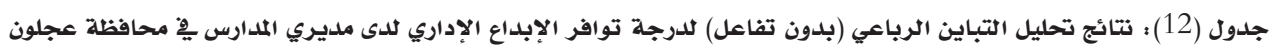

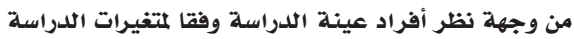

\begin{tabular}{|c|c|c|c|c|c|}
\hline الدلالة الإحصائية & قيمة F & وسط المربعات & درجات الحرية & مجموع المربعات & مصدر التباين \\
\hline 0.29 & 1.134 & 0.861 & 1 & 0.861 & الجنس \\
\hline 0.11 & 2.507 & 1.904 & 1 & 1.904 & المؤهل العلمي \\
\hline
\end{tabular}


جدول (12) : يتبع

\begin{tabular}{|c|c|c|c|c|c|}
\hline الدلالة الإحصائية & قيمة F & وسط المربعات & درجات الحرية & مجموع المربعات & مصدر التباين \\
\hline \multirow[t]{3}{*}{0.79} & 0.069 & 0.052 & 1 & 0.052 & المرحلة التعليمية \\
\hline & & 0.759 & 346 & 262.764 & الخطأ \\
\hline & & & 349 & 265.581 & الكلي \\
\hline
\end{tabular}

يتضح من النتائج ِِّ الجدول (12) عدم وجود فروق دالة إحصائيا عند مستوى الدلالة الإحصائية (05.05)

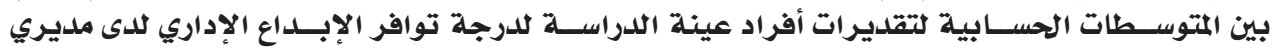

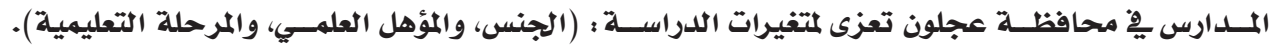

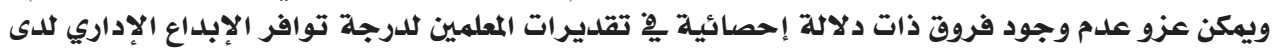

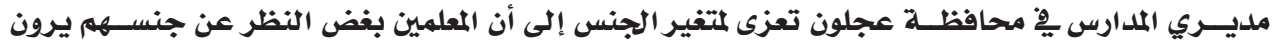

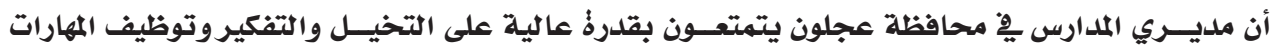

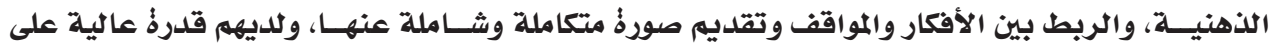

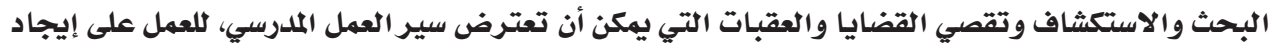

الحلول المناسبة لها.

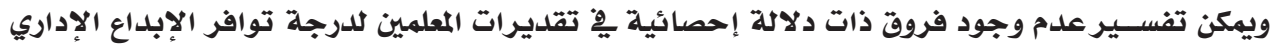

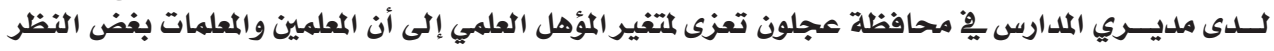

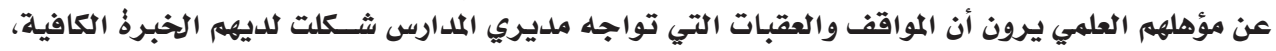

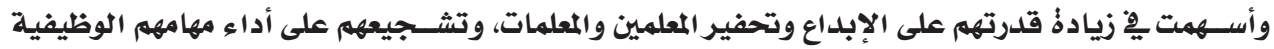

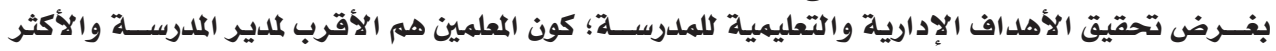

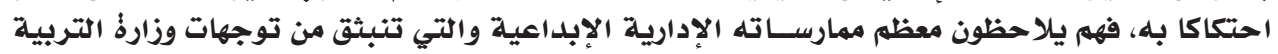

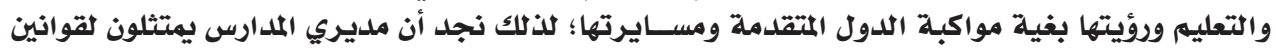

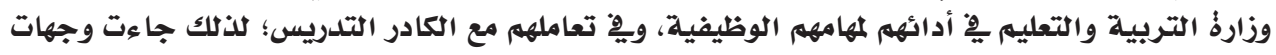
نظر المعلميين متقاربة.

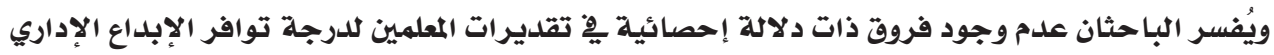

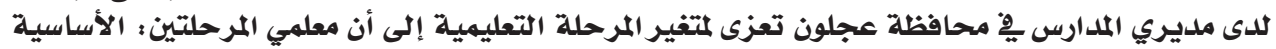

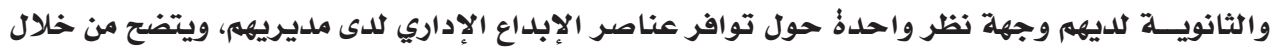

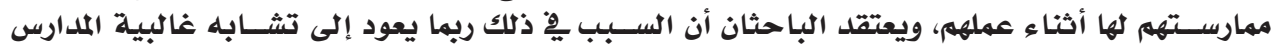

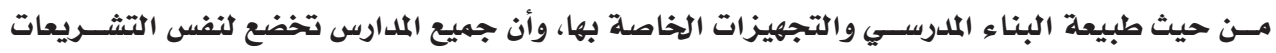

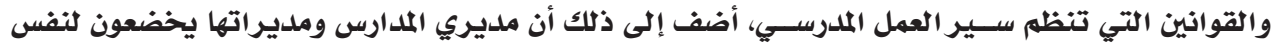

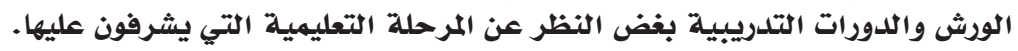

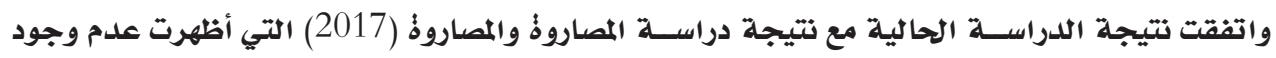

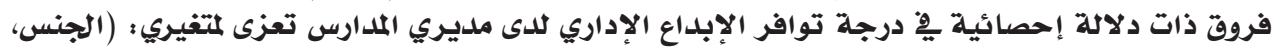

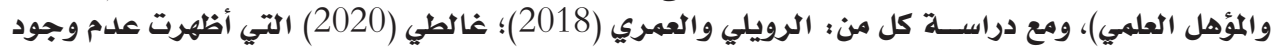

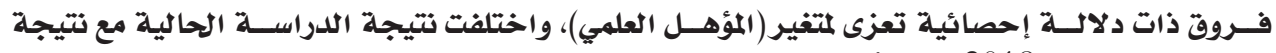

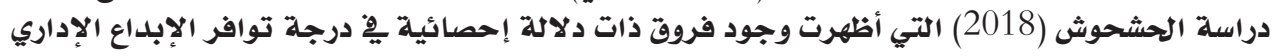

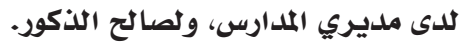




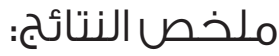

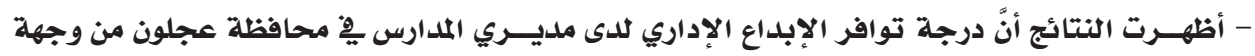

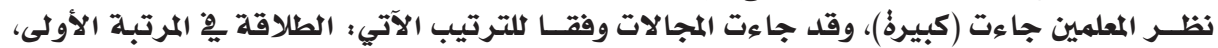

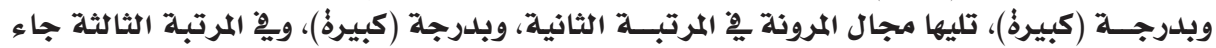

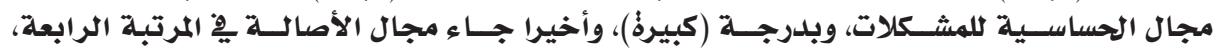

$$
\text { وبلدرجة (كبيرة). }
$$

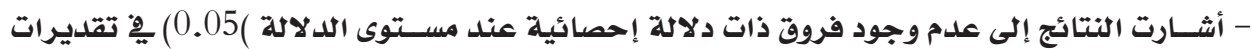

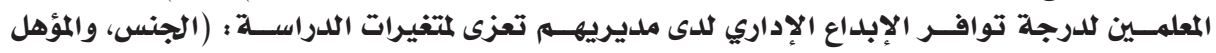

العلمي، والمرحلة التعليمية).

التوصيات:

مِّ ضوء نتائج الدراسة أوصى الباحثان بالآتي:

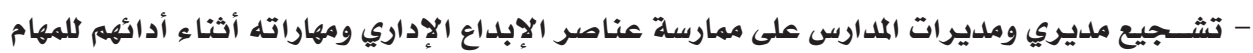

الوظيفية المنوطة بهم.

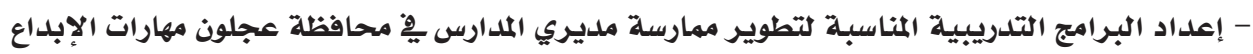

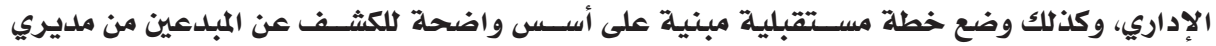

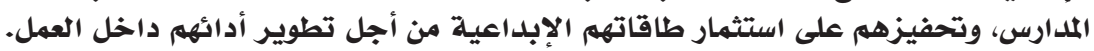

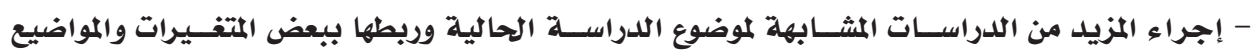
الإدارية ذات المزيلة من الدرات الصلة.

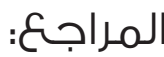

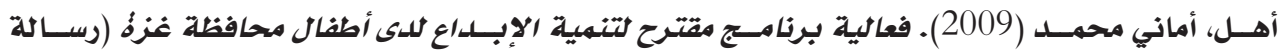

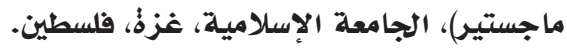

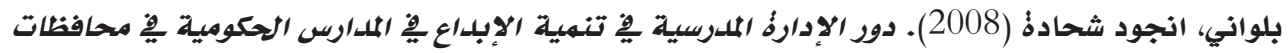

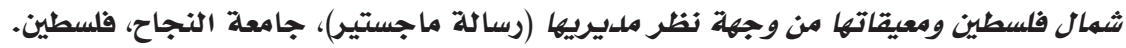

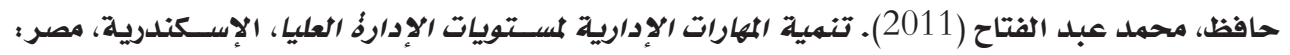
مؤسسة حوريس عيل الدئاح الدولية للنشر والتوزيع.

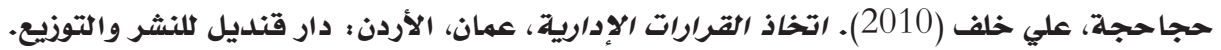

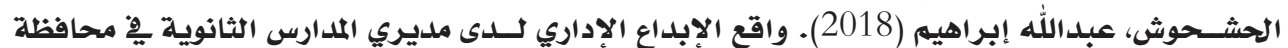

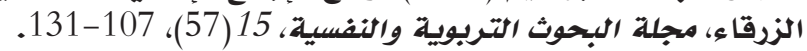

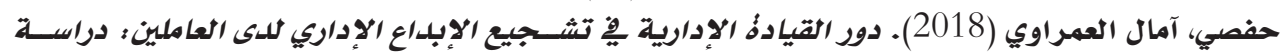

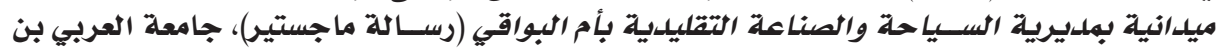

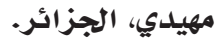

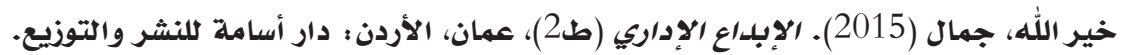

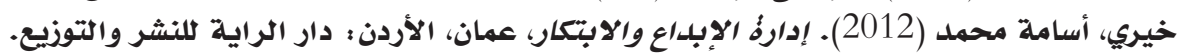

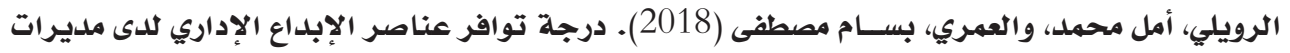

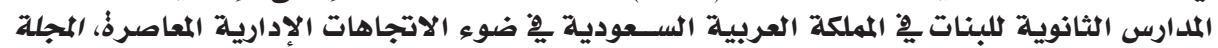

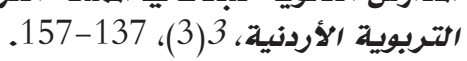

السكارنة، بلال خلف (2011). الإبلداع الإداري، عمان، الأردن : دار المسيرةٌ للنشر والتوزيع والطباعة. 
حسني أنعام سالم تغريد رضوان المومني

المجلد الثاني عشر العدد (22) 2021م ألمريد رضوان المومي

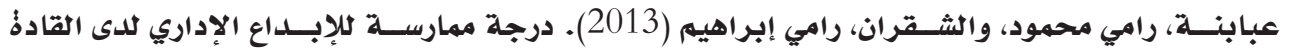

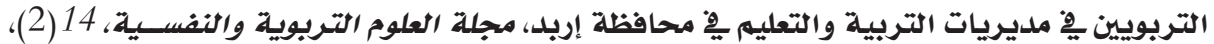

.486-459

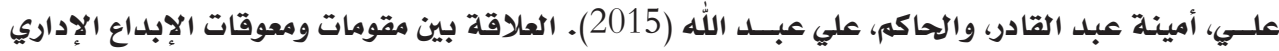

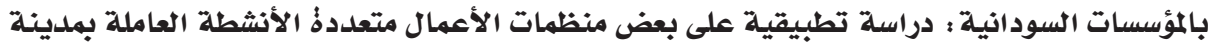

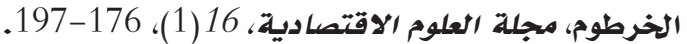

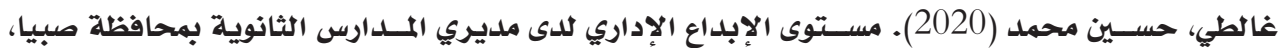

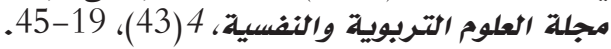

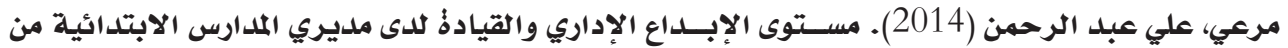

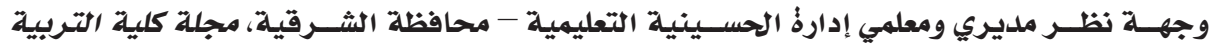

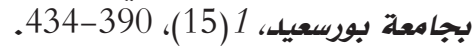

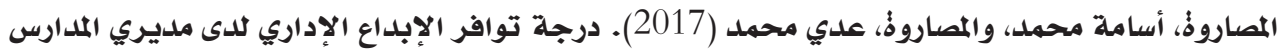
الحكومية يِّ لواء بني عبيد من وجهة نظر المعلمين، مجلة جامعة النجاح لكأبحاث: العلوم الإنسانية، 32-1، 31 31

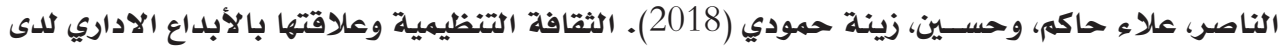

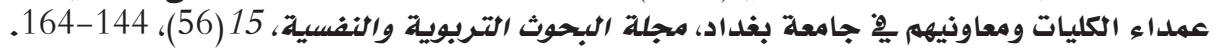

Abdul-Aal, A. M \& Alshammri, F. S. (2018). The reality of administrative creativity among the principals of general secondary education schools: A field study in Sohag City. Global Journal of Management and Business Research. 18 (13), 16-23.

Al-Saudi, M. A. (2012). The impact of organizational climate upon the innovative behavior at Jordanian private universities as perceived by employees: A field study. International Business and Management, 5(2), 14-27.

Dagytė, I. (2010). Creative self-management as a tool of enhancing innovation's portfolio of business organization. Management Theory and Studies for Rural Business and Infrastructure Development, 24(5), 33-44.

Gulşen, C. (2014). The Readiness Levels of Secondary School Administrators to the Innovation Management. International Journal on New Trends in Education and Their Implications, 5(2), 77-86.

Hewison, R., \& Holden, J. (2016). The cultural leadership handbook: how to run a creative organization. London: Routledge.

Kodama, M. (ed.). (2017). Ma Theory and the Creative Management of Innovation. London: Palgrave Macmillan.

Shaheen, R. (2018). A qualitative investigation to develop Interior design pedagogy that foster students' creativity (Doctoral dissertation). Anglia Ruskin University, Cambridge, England. 


\section{Arabic References in Roman Scripts:}

Ababneh, Rami Mahmoud, wa Al-Shaqran, Rami Ibrahim (2013). Darajat mumarasat lil'iibdae al'iidarii ladaa alqadat altarbawiiyn fi mudiriaat altarbiat waltaelim fi muhafazat Irbid, Majalat Aleulum Altarbawiat Walnafsiati, 14(2), 459-486.

Ahl, Amani Muhammad (2009). Faeaaliat barnamai muqtarah litanmiat al'iibdae ladaa 'atfal muhafazat Ghaza (Risalat majistir), Aljamieat Al'iislamiati, Ghaza, Filastin.

Al-Hashhoush, Abdullah Ibrahim (2018). Waqie al'iibdae al'iidarii ladaa mudiri almadaris althaanawiat fi muhafazat Alzarqa'i, Majalat Albuhuth Altarbawiat Walnafsiati, 15(57), 107-131.

Ali, Amina Abdel-Qader, wa Al-Hakim, Ali Abdullah (2015). Alealaqat bayn muqawimat wamueawiqat al'iibdae al'iidarii bialmuasasat alsuwdaniati: dirasat tatbiqiatan ealaa baed munazamat al'aemal mutaeadidat al'anshitat aleamilat bimadinat alkhartum, Majalat Aleulum Alaiqtisadiati, 16(1), 176197.

Al-Masarwe, Osama Muhammad, wa Al-Masarwe, Uday Muhammad (2017). Darajat tawafur al'iibdae al'iidarii ladaa mudiri almadaris alhukumiat fi liwa' bani eubayd min wijhat nazar almuealimina, Majalat Jamieat Alnajah Lil'abhath: Aleulum Al'iinsaniati, 37(9), 1-32.

Al-Nasser, Alaa Hakem, wa Hussein, Zeina Hamoudi (2018). Althaqafat altanzimiat waealaqatuha bial'abdae aladarii ladaa eumada' alkuliyaat wamueawinihim fi jamieat Baghdad, Majalat Albuhuth Altarbawiat Walnafsiati, 15(56), 144-164.

Al-Ruwaili, Amal Muhammad, wa Al-Omari, Bassam Mustafa (2018). Darajat tawafur eanasir al'iibdae al'iidarii ladaa mudirat almadaris althaanawiat lilbanat fi almamlakat alearabiat alsaeudiat fi daw' alaitijahat al'iidariat almueasirati, Almajalat Altarbawiat Al'urduniyata, 3(3), 137-157.

Al-Sakarna, Bilal Khalaf (2011). Al'iibdae al'iidaria, Amman, Al'urdunu: Dar Almasirat Lilnashr Waltawzie Waltibaeati.

Balwani, Anjoud Shehadeh (2008). Dawr al'iidarat almadrasiat fi tanmiat al'iibdae fi almadaris alhukumiat fi muhafazat shamal filastin wamueiqatiha min wijhat nazar mudiriha (Risalat majistir), Jamieat Alnajahi, Filastin.

Galati, Hussein Muhammad (2020). Mustawaa al'iibdae al'iidarii ladaa mudiri almadaris althaanawiat bimuhafazat Sibya, Majalat Aleulum Altarbawiat Walnafsiati, 4(43), 19-45.

Hafez, Mohamed Abdel Fattah (2011). Tanmiatalmaharat al'iidariat limustawayat al'iidarat aleulya, Al'iiskandiriat, Misr: Muasasat Hurs Alduwliat Lilnashr Waltawziei. 
حسني أنعام سالم تغريد رضوان المومني

المجلد الثاني عشر العدد (22) 2021 تفريل رضوان المومني

Hafsi, Amal El-Amraoui (2018). Dawr alqiadat al'iidariat fi tashiie al'iibdae al'iidarii ladaa aleamilina: dirasat maydaniat bimudiriat alsiyahat walsinaeat altaqlidiat bi'umi albawaqi (Risalat majistir), Jamieat Alearabii bin Mahidi, Aljazayar.

Haijajeh, Ali Khalaf (2010). Aitikhadh alqararat al'iidariati, Amman, Al'urdunu: Dar Qandil Lilnashr Waltawziei.

Khairallah, Jamal (2015). Al'iiibdae al'iidariu (Taba'a 2), Amman, Al'urdunu: Dar Osama Lilnashr Waltawziei.

Khairi, Osama Muhammad (2012). 'lidarat al'iibdae waliabtikar, Amman, Al'urdunu: Dar Alraayat Lilnashr Waltawziei.

Murei, Ali Abdul Rahman (2014). Mustawaa al'iibdae al'iidarii walqiadat ladaa mudiri almadaris alaibtidayiyat min wijhat nazar mudiri wamuealimi 'iidarat alhusayniat altaelimiat - muhafazat Alsharqia, Majalat Kuliyat Altarbiat bi Jamieat Bursaeid, 7(15), 390-434. 